\title{
ROZWÓJ MIAST I URBANIZACJA BRAZYLII W OKRESIE KOLONIALNYM (1500-1822)
}

\section{CITIES DEVELOPMENT AND URBANIZATION OF BRAZIL IN THE COLONIAL PERIOD (1500-1822)}

DOI: $10.25167 / \mathrm{sm} 2017.025 .02 \quad$ s. $31-57$

\begin{abstract}
ABSTRAKT: Celem artykułu jest przedstawienie historii powstania i ewolucji miejskiej sieci osadniczej Brazylii w okresie jej zależności kolonialnej od Portugalii. Określono również zmiany tempa zakładania miast oraz różnice w ich przestrzennym rozmieszczeniu, starając się powiązać te zagadnienia z przemianami gospodarczymi i politycznymi zachodzącymi w Brazylii wraz z postępującą kolonizacją. Podjęto także próbę określenia i uwzględnienia w analizie wpływu uwarunkowań międzynarodowych na rozwój i zróżnicowanie przestrzenne brazylijskiej sieci miejskiej. Uzyskane wyniki wskazują, że w trwającym ponad 300 lat okresie kolonialnym ukształtowały się podwaliny miejskiej sieci osadniczej Brazylii, na którą składało się 12 miast oraz ponad 200 miasteczek. Większość z powstałych wówczas ośrodków do dziś odgrywa ważną rolę w systemie osadniczym. Przeprowadzone badania wskazują, że rozwój sieci brazylijskich miast nawiązywał do modelu merkantylnego Vance’a, ale także teorii rozwoju ośrodków w układzie typu system - sieci (network system) oraz koncepcji miast bram (gateway cities).
\end{abstract}

SŁOWA KLUCZOWE: Brazylia, kolonizacja, sieć miejska, miasta bramy, model merkantylny osadnictwa

ABSTRACT: The aim of this article is to present the history of the origin and evolution of the urban settlement network in Brazil during its colonial dependency on Portugal. The change in the pace of the establishment of cities and the differences in their spatial distribution were also determined, and an attempt was made to link these issues to the economic and political changes taking place in Brazil, including the progressing colonization. An attempt was also made to identify and take into account, in the analysis, the impact of international conditions for the development and spatial differentiation of the Brazilian urban network. The results indicate that in the over three-hundred-year colonial period the foundations of the urban settlement in Brazil were formed, which consisted of 12 cities and over 200 towns. Most of the centers formed at that time have continued to play an important role in the settlement system until today. The undertaken studies indicate that the development of the network of Brazilian cities referred to Vance's mercantile model, but also to the network system theory of cities development and to the concept of gateway cities.

KEY WORDS: Brazil, colonization, urban network, gateway cities, mercantile model of settlement

* Uniwersytet Pedagogiczny w Krakowie, Instytut Geografii, ul. Podchorążych 2, 30-084 Kraków, tel. 1266262 65, e-mail: mwojt@up.krakow.pl 


\section{Wprowadzenie}

Obszar współczesnej Brazylii w momencie odkrycia przez Portugalczyków był pozbawiony miast, a większość zamieszkujących go plemion prowadziła koczowniczy tryb życia. Bardzo rozproszeni i stosunkowo nieliczni pierwotni mieszkańcy tych ziem pozostawali na niskim poziomie rozwoju społecznego, co w przeciwieństwie do wysoko rozwiniętych cywilizacji, na jakie natrafili Hiszpanie na obszarze współczesnego Meksyku i Peru, sprawiało, iż podbój i kolonizacja tego obszaru wydawały się ówczesnym decydentom zadaniem znacznie trudniejszym, mniej opłacalnym, a przez to niezbyt uzasadnionym (Colonial Brazil... 1987, Kula 1987, Skidmore 1999). Kolonizacja Brazylii wiązała się także z koniecznością stworzenia od podstaw miejskiej sieci osadniczej przy jednoczesnym zapewnieniu ekonomicznych podstaw jej funkcjonowania i dalszego rozwoju. Brak cennych surowców mineralnych (jak złoża srebra czy złota) oraz niewielka liczba i niski poziom rozwoju pierwotnych mieszkańców tych ziem zmusiły Portugalczyków do przyjęcia innej strategii kolonizacji w porównaniu do obszarów Hispanoameryki (Furtado 1967, Johnson 1987).

Celem artykułu jest zbadanie czy, a jeżeli tak, to w jakim stopniu, historia powstawania i ewolucji miejskiej sieci osadniczej Brazylii w okresie jej zależności kolonialnej od Portugalii nawiązuje do teorii i modeli rozwoju osadnictwa na dziewiczych obszarach takich jak: merkantylny model osadnictwa Jamesa E. Vance'a Jr. (1971), teoria rozwoju miast w układzie typu system - sieci (network system) Paula M. Hohenberga i Lynn H. Lees (1995), a także koncepcja miast bram (gateway cities) (Burghardt 1971, Bird 1973, 1983) czy rozwoju transportu jako czynnika kształtującego sieć osadniczą na obszarach niedorozwiniętych (Taaffe, Morrill, Gould 1963). W pracy przeanalizowano również zmiany tempa zakładania miast oraz różnice w przestrzennym ich rozmieszczeniu, starając się powiązać te zagadnienia z przemianami gospodarczymi i politycznymi zachodzącymi w Brazylii wraz z postępującą kolonizacją. Podjęto także próbę określenia i uwzględnienia w analizie wpływu uwarunkowań międzynarodowych na rozwój i zróżnicowanie przestrzenne brazylijskiej sieci miejskiej, mając na uwadze fakt, iż obszar ten był bardzo silnie związany ekonomicznie z tworzącym się od XVI w. kapitalistycznym systemem-światem (Wallerstein 2011).

Tak postawione założenia badawcze miały na celu połączenie opisowych informacji dotyczących chronologii i przestrzennego rozwoju miejskiej sieci Brazylii z teoriami wyjaśniającymi i modelowymi ujęciami tłumaczącymi tworzenie się osadnictwa na obszarach kolonizacji europejskiej. Pozwoliło to na bardziej kompleksowe przedstawienie polskim czytelnikom bardzo ważnego okresu kształtowania się głównych zrębów miejskiej sieci osadniczej Brazylii, z uwzględnieniem szerszej podbudowy teoretycznej i tła historyczno-ekonomicznego rozwijającego się światowego systemu kapitalistycznego.

\section{Teoretyczne podstawy badania rozwoju sieci miejskich na obszarach kolonizowanych}

Do wyjaśnienia powstania i początkowego rozwoju sieci osadniczej Brazylii nieprzydatna okazuje się klasyczna teoria ośrodków centralnych opracowana przez Waltera 
Christallera (1963). Zakłada ona bowiem, że tworzenie się sieci osadniczej jest napędzane przez czynniki endogeniczne wynikające z popytu na określone dobra i usługi, który jest generowany przez ludność, cechującą się podobną siłą nabywczą i równomiernie rozmieszczoną na jednolitej pod względem zasobów surowcowych i warunków transportowych równinie. Każde z oferowanych dóbr i usług ma swój własny zasięg rynkowy, na podstawie którego można określić jego hierarchię. Zasięg ten można z kolei określić na podstawie liczby konsumentów zapewniających przedsiębiorstwu oferującemu dany towar lub usługę takie zyski, że może się ono utrzymać na rynku w warunkach wolnej konkurencji. Wyznacznikiem centralności (miejsca w hierarchii) danego dobra lub usługi jest zarówno liczba ludności przybywająca z regionu w celu ich nabycia, jak również powyżej której nie są już one nabywane. Biorąc pod uwagę przedstawione skrótowo główne założenia teorii ośrodków centralnych, łatwo zauważyć, iż jej zastosowanie do wyjaśnienia tworzenia się sieci osadniczej ma uzasadnienie tylko w przypadku obszarów o długich tradycjach osadnictwa rolniczego przygotowujących warunki do dalszego rozwoju i różnicowania się hierarchicznego (wielkościowego) ośrodków (Maik 1988).

W przypadku kolonizacji dziewiczych terenów zdecydowanie większe walory eksplikacyjne ma merkantylny model rozwoju osadnictwa zaproponowany przez J.E. Vance'a (1971). Zakłada on, że główną rolę w tworzeniu się sieci osadniczej na nowo zagospodarowywanym obszarze mają czynniki egzogeniczne - zewnętrzny popyt na określone surowce lub produkty dostępne bądź wytwarzane na tym obszarze a konsumowane przez ludność metropolii. Model ten powstał na bazie analizy europejskiej ekspansji kolonialnej w Ameryce Północnej w okresie merkantylizmu i początków tworzenia się kapitalistycznego systemu-świata, którego centrum stanowiły państwa Europy Zachodniej rozwijające swoje kolonialne imperia i zgłaszające coraz większe zapotrzebowanie na produkty konsumpcyjne i surowce dla rozwoju własnego przemysłu (Vance 1971, Wallerstein 2011).

Merkantylny model rozwoju sieci osadniczej składa się z pięciu następujących po sobie etapów wynikających z postępów kolonizacji. Pierwszy etap - eksploracji - wiąże się z okresem odkryć geograficznych. Przybywający ze „starego świata” żeglarze badają nowy ląd, zbierają informacje handlowe o jego zasobach i bogactwach, na które może być zapotrzebowanie w metropolii. Drugi etap to testowanie produktywności nowych ziem oraz pozyskiwanie łatwo dostępnych bogactw naturalnych (ryby, drewno, futra) niewymagające jeszcze tworzenia stałych osiedli. W trzecim etapie pojawiają się już pierwsze stałe osiedla, rozwija się również produkcja rolnicza na potrzeby kolonistów. Powstaje ośrodek portowy - punkt złączenia (point of attachment) - pełniący rolę miasta bramy (gateway city). W głębi lądu, wzdłuż głównych szlaków penetracji, również tworzą się pierwsze osady. W czwartym etapie w wyniku wzrostu potencjału demograficznego i ekonomicznego kolonii dochodzi do rozwoju rynku wewnętrznego i początków lokalnej produkcji. Rozwijają się także dynamicznie szlaki komunikacyjne, a osadnictwo przesuwa się w głąb kontynentu. Rosnący rynek wchłania coraz większe ilości towarów sprowadzanych z metropolii, napędzając tym samym jej industrializację 
i wzrost liczby ludności. W ostatnim - piątym - etapie dojrzałości ekonomicznej merkantylny model sieci osadniczej ukształtowany w oparciu o dużą wymianę handlową z zagranicą zostaje zdominowany przez handel wewnętrzny, co sprawia, że sieć osadnicza jest coraz silniej kształtowana przez siły wskazane w teorii ośrodków centralnych. System osadniczy staje się wewnętrznie zintegrowany i niezależny od byłej metropolii. Warto jeszcze dodać, iż choć w modelu Vance'a wymiana handlowa między metropolią a kolonią generalnie warunkuje tworzenie się sieci osadniczej na obszarze kolonizowanym, podczas gdy w metropolii system osadniczy kształtuje się generalnie w myśl teorii ośrodków centralnych, to jednak w wyniku długotrwałego rozwoju handlu dochodzi do nałożenia się na niego także impulsów wypływających z modelu merkantylnego. Efektem tego jest uwypuklenie w sieci osadniczej metropolii miast cechujących się najlepiej rozwiniętymi powiązaniami zewnętrznymi (Vance 1971) (rysunek 1).

Do wyjaśnienia początków tworzenia się brazylijskiej sieci miast użyteczna wydaje się również teoria rozwoju miast w układzie typu system - sieci, która została zaproponowana przez P. Hohenberga i L.H. Lees w wydanej po raz pierwszy w 1985 r. pracy: Making of urban Europe 1000-19501. Nie jest to teoria konkurencyjna wobec koncepcji ośrodków centralnych, zaś jej autorzy wskazują na współwystępowanie obu układów lokalizacyjnych, a w niektórych obszarach nawet ich nakładanie się. W teorii systemu - sieci główną siłą napędzającą urbanizację są powiązania i wymiana handlowa między miastami, które tworzą centra, węzły, skrzyżowania, wysunięte placówki i przekaźniki sieci. Tworząca się sieć handlowa opiera się, bezpośrednio lub pośrednio, na produkcji rolniczej, ponieważ to obszary wiejskie dostarczają surowców do handlu i żywności dla mieszkańców miast oraz stanowią potencjalne duże niewykorzystane rynki zbytu dla będących w obiegu handlowym towarów. Biorąc te uwarunkowania pod uwagę, autorzy teorii zauważyli, iż pierwotnie rolnicze obszary mogą rozwinąć swoją sieć miejską w sposób niemal całkowicie odmienny niż przewiduje teoria ośrodków centralnych. Zakładają oni bowiem, że początkowe centrum pełni rolę bramy, łącznika do szerszej sieci i zazwyczaj zostaje głównym miastem regionu. Z niego rozchodzą się bodźce do produkcji większych nadwyżek, opierając się na niedostatecznie wykorzystanych rezerwach ziemi lub pracy w regionie. Tworzące się mniejsze ośrodki pełnią głównie funkcje gromadzenia, magazynowania i przesyłania surowców i upraw eksportowych, a wtórnie zajmują się redystrybucją napływających w zamian towarów i świadczeniem innych usług centralnych. Jeżeli napędzany eksportem rozwój się powiedzie, z czasem doprowadzi on do wykształcenia sieci ośrodków centralnych bazujących na lokalnym handlu. Szybkość i siła, z jakimi może rozwijać się ten proces, zależą, według autorów, w dużej mierze od charakteru eksportowanego towaru oraz rozwoju i pomyślności handlu. Zakładają oni, że rolnictwo bazujące na uprawie ziemi zapuszcza silniejsze korzenie niż pasterstwo, rybołówstwo jest lepsze niż myślistwo, natomiast w przypadku

\footnotetext{
1 Założenia tej teorii na gruncie polskim zostały spopularyzowane w pracach A. Wyrobisza (1989) oraz R. Krzysztofika (2009), dlatego w dalszej części zaprezentowane zostaną tylko jej główne założenia mające zastosowanie w analizowanym przypadku rozwoju brazylijskiej sieci miejskiej.
} 
Model merkantylny

Bazujący na siłach zewnętrznych wprowadzających podstawowe struktuy

Model miejsc centralnych

Na początku bazuje na rolnictwie endogenicznie sortującym i porządkującym sieć osadniczą

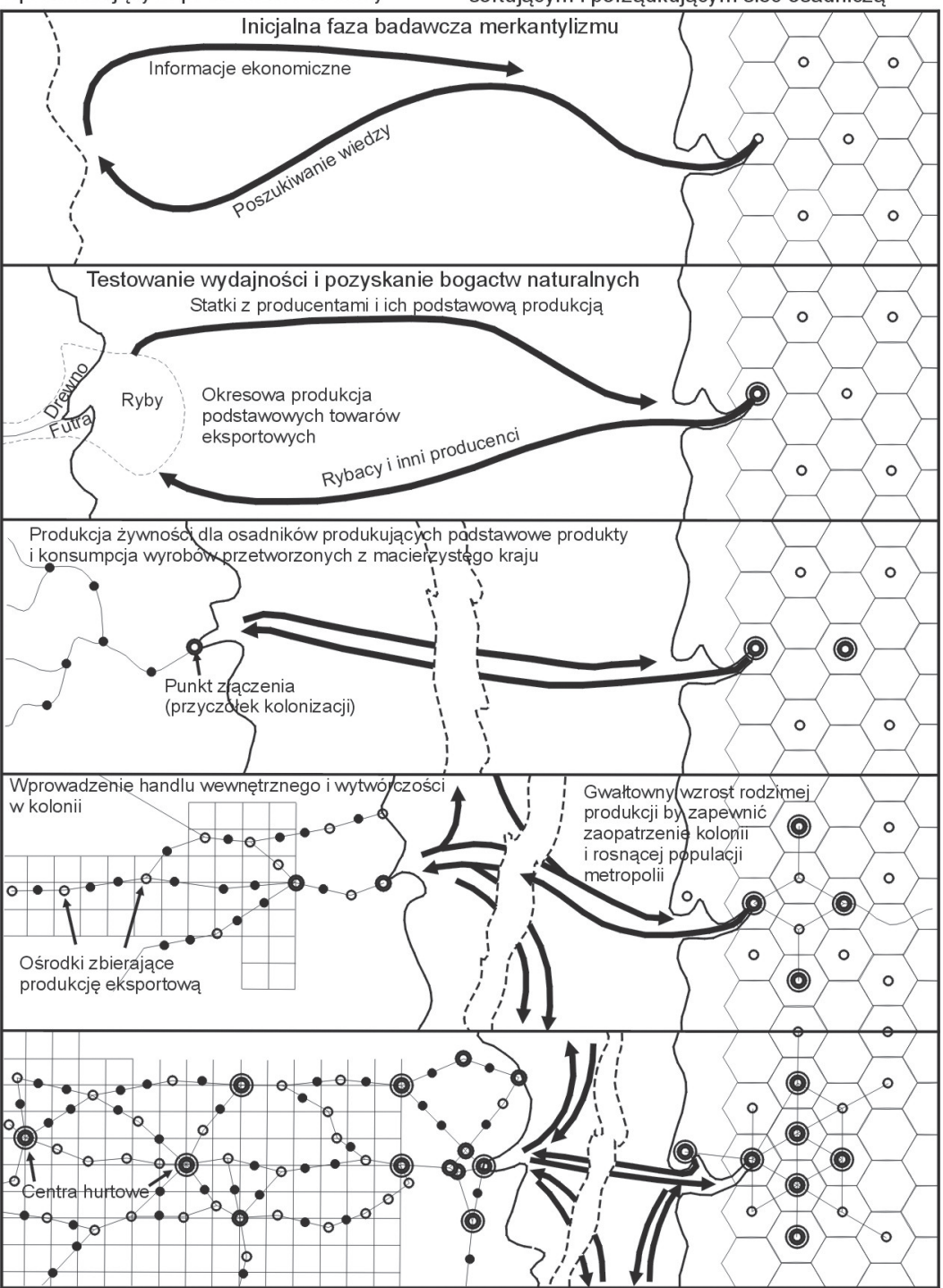

Rys. 1. Merkantylny model rozwoju sieci osadniczej

Źródło: Opracowanie własne na podstawie: Vance 1971, s. 151.

leśnictwa i górnictwa wyniki mogą być bardzo zróżnicowane (Hohenberg, Lees 1995, s. 62-63).

Autorzy modelu system - sieci wskazują także na odmienne względem modelu ośrodków centralnych siły ekonomiczne, kierunki ich działania oraz głównych akto- 
rów odpowiedzialnych za rozwój sieci miejskiej. W modelu christallerowskim rozwój gospodarczy dokonywał się od podstawy hierarchii osadniczej, był napędzany głównie wzrostem podaży, za którym stali producenci (rolnicy i rzemieślnicy). Natomiast w modelu system - sieci rozwój jest napędzany od centrum systemu w wyniku wzrostu i rozszerzania się popytu, którego głównymi aktorami są handlowcy (kupcy i bankierzy) (Hohenberg, Lees 1995, s. 65).

Z zaprezentowaną powyżej teorią systemu - sieci wiąże się także koncepcja tzw. miast-wrót (gateway cities) rozwijana intensywnie na przełomie lat 70. i 80. XX w. (Burghardt 1971, Bird 1973, 1983, Simmons 1983). Na gruncie polskim koncepcja ta została zaprezentowana i szeroko omówiona (Krzysztofik 2003, 2004), co pozwala skupić się w dalszej części jedynie na przedstawieniu zagadnień istotnych z punktu widzenia dalszej analizy. Koncepcja miast bram jest szczególnie pomocna w analizie rozwoju sieci osadniczej na obszarach kolonizowanych, gdyż tego typu ośrodki tworzą się najczęściej na granicy między obszarami o zróżnicowanym poziomie zagospodarowania, różnej gęstości zaludnienia lub typie działalności produkcyjnej. Charakteryzują się one punktami wejścia i wyjścia z jednego regionu do drugiego i można podzielić je na dwa typy: miasta bramy petniące rolę węztów (connecting nodes) łączących strumienie przepływu towarów i usług między dobrze zagospodarowanym i zaludnionym centrum kraju a kolonizowanymi pograniczami oraz miasta bramy będące ogniwami łączącymi dwie niezależnie rozwinięte sieci osadnicze. W drugim przypadku szczególnie często znajdują się porty łączące dany kraj ze światem, miasta na granicy międzypaństwowej lub na styku dwóch regionów o odmiennej historii rozwoju społeczno-ekonomicznego utrwalonej w odmiennościach sieci osadniczej i sposobach gospodarowania (Burghardt 1971, s. 282-283, Bird 1973, s. 111-112).

Warto jeszcze wspomnieć, iż miasta-bramy powstające w obszarach nowej kolonizacji mogą z czasem przekształcić się w ośrodki o charakterze miejsc centralnych. Jeżeli obszar, na którym leżą, okaże się wysoko produktywny i zostanie zasiedlony oraz zagospodarowany, to leżące na nim miasto-wrota przekształci się w ośrodek o funkcjach miejsca centralnego, zachowując jednak znacznie rozbudowane funkcje węzła komunikacyjnego w porównaniu do innych ośrodków centralnych będących na podobnym poziomie w hierarchii. Skurczy się jednak jego obszar obsługi, szczególnie od strony odsuwającej się granicy, gdzie pojawią się nowe konkurencyjne ośrodki (Burghardt 1971, s. 272-273, Krzysztofik 2004, s. 216). Rozważania na temat roli miast-bram w kolonizacji dziewiczych terenów Andres Burghardt trafnie podsumowuje w ostatnim zdaniu artykułu: „Mówiąc prościej, można stwierdzić: A) miasta bramy «organizują» tereny wiejskie; a wtedy B) tereny wiejskie «organizują» ośrodki centralne" (Burghardt 1971, s. 285).

Koncepcja miast-bram bardzo często była wykorzystywana do wyjaśnienia tworzenia się systemu miejskiego na obszarach nowej kolonizacji (Simmons 1983). James W. Simmons w swojej wcześniejszej pracy zaproponował cztery modele organizacji systemu miejskiego, z których dwa pierwsze: model graniczno-handlowy (Frontier-Mercantile) oraz model eksportu produkcji podstawowej (Staple-Export), zakładają ważną rolę 
miast-bram w tworzeniu się sieci osadniczej i rozwijają się w podobnych uwarunkowaniach ekonomiczno-handlowych jak brazylijska sieć miejska w okresie kolonialnym (Simmons 1983, s. 59, Krzysztofik 2003, s. 334-335). W pierwszym przypadku system jest zdominowany przez siły ekonomiczne płynące z regionu źródłowego, z którego napływa siła robocza, kapitały i dobra potrzebne do dalszej kolonizacji. Jeden lub dwa główne ośrodki rozdysponowują je w dół hierarchii osadniczej, która maleje w miarę zbliżania się do granicy kolonizowanego obszaru. Wytwarzane na zagospodarowywanym obszarze produkty wracają w odwrotnym kierunku do obszaru źródłowego, jednakże ze względu na słabą specjalizację produkcji dominują przepływy od regionu rdzeniowego w kierunku strefy nadgranicznej (rysunek 2).

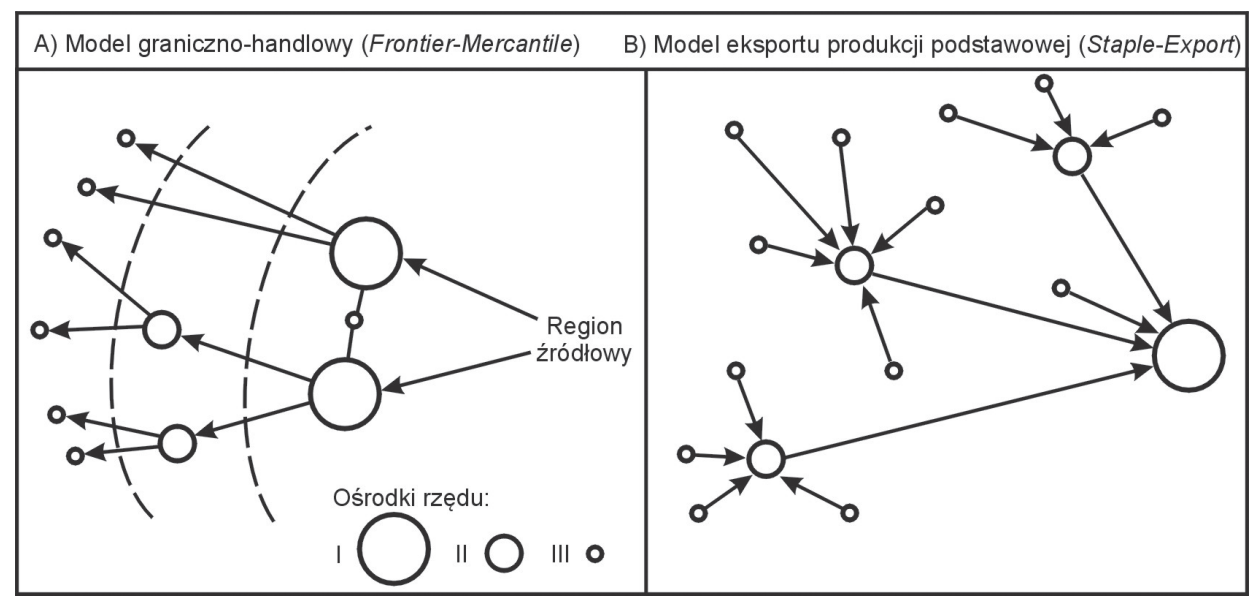

Rys. 2. Modele organizacji systemu miejskiego na obszarach kolonizowanych

Źródło: opracowanie własne na podstawie: Simmons 1983, s. 59.

W przypadku modelu eksportu produkcji podstawowej przepływy towarowe uzależnione są od popytu zewnętrznego. Dominuje przepływ towarów eksportowych w górę hierarchii osadniczej od ośrodków zbierających lokalną produkcję w obszarach kolonizacji rolniczej (najczęściej rolnictwa plantacyjnego), poprzez centra regionalne aż do głównego miasta (portu) wysyłającego ją do zewnętrznych odbiorców. Sieć miejska kształtuje się według reguły wielkości - kolejności i najczęściej rozwija się na obszarach peryferyjnych, ale nie w bezpośrednim sąsiedztwie strefy kolonizacji dziewiczych terenów (rysunek 2).

Bardzo ważną rolę w tworzeniu sieci osadniczej oraz zagospodarowaniu dziewiczych terenów odgrywa sieć transportowa. Od samego początku jej ekspansja jest procesem ciągłej dyfuzji przestrzennej, którego nieregularności wynikają z wielu specyficznych czynników ekonomicznych, społecznych, politycznych a także oporu, jaki stawiają warunki naturalne. Powstające korytarze komunikacyjne wykorzystują najczęściej korzystne uwarunkowania środowiska przyrodniczego umożliwiające najłatwiejszą 
dyfuzję sieci transportowej, wraz z którą postępuje także rozwój miejskiej sieci osadniczej (Whebell 1969). W obszarach dziewiczych rozwój transportu może w istotny sposób warunkować rozwój i wpływać na kształt sieci osadniczej. Do próby wyjaśnienia wpływu transportu na rozwój miejskiej sieci Brazylii zasadne wydaje się wykorzystanie modelu rozwoju systemu osadniczo-transportowego opracowanego przez Edwarda J. Taaffe'a, Richarda L. Morrilla i Petera R. Goulda (1963) opracowanego dla kolonizowanych wybrzeży Afryki (rysunek 3).

Przedstawiony model składa się z sześciu faz. W pierwszej (A) dochodzi do powstania rozrzuconej wzdłuż wybrzeża sieci faktorii i małych portów, z których każdy

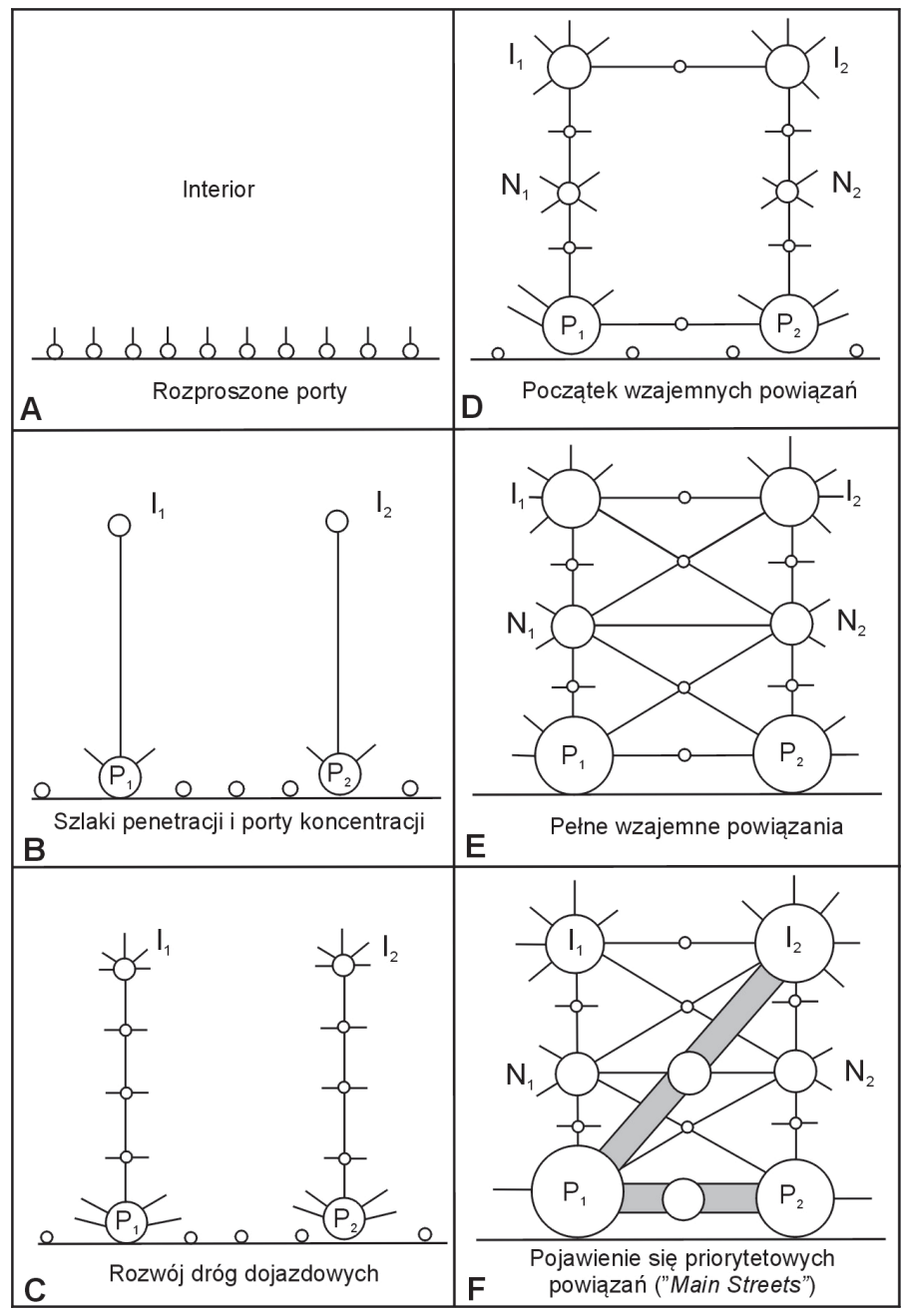

Rys. 3. Model rozwoju systemu osadniczo-transportowego na obszarach kolonizowanych Źródło: opracowanie własne na podstawie: Taaffe, Morrill, Gould 1963, s. 504. 
posiada własne małe zaplecze handlowe wewnątrz lądu i praktycznie nie utrzymuje żadnych kontaktów z innymi portami. W kolejnej fazie (B) dochodzi do rozwoju głównych linii transportowych w głąb lądu, co obniża koszty transportu do wybranych portów i napędza ich szybszy wzrost. W trzeciej fazie (C) wykształcone wcześniej drogi dojazdowe łączące leżące w interiorze ośrodki z portami premiują ich dalszy rozwój i tworzenie się między nimi ośrodków pośrednich wytwarzających wokół siebie własne zaplecze. W czwartej fazie (D) dalszy rozwój głównych korytarzy transportowych pozwala dominującym portom zwiększyć swoje zaplecze kosztem sąsiednich mniejszych portów. Mniejsze węzły $\left(\mathrm{N}_{1}, \mathrm{~N}_{2}\right)$ rozwijające się na głównych liniach penetracji stają się punktami centralnymi swoich własnych sieci dróg dojazdowych. W piątej fazie (E) wraz z dalszym rozwojem sieci transportowej dochodzi do wykształcenia się bezpośrednich połączeń także pomiędzy głównymi ośrodkami w interiorze $\left(\mathrm{I}_{1}, \mathrm{I}_{2}\right)$, największymi węzłami $\left(\mathrm{N}_{1}, \mathrm{~N}_{2}\right)$ na głównych szlakach oraz głównymi portami $\left(\mathrm{P}_{1}, \mathrm{P}_{2}\right)$. Autorzy modelu zakładają, że jego ostatnią fazą (F) jest wykształcenie się z czasem krajowych magistrali komunikacyjnych łączących najszybciej rozwijające się ośrodki. Będzie to wynikiem postępującego procesu koncentracji działalności gospodarczej, ludności i kapitału w wybranych miastach $\left(\mathrm{I}_{2}, \mathrm{P}_{1}, \mathrm{P}_{2}\right)$, rozwijających się szybciej kosztem innych ośrodków i wymuszających ukształtowanie się między nimi priorytetowych powiązań komunikacyjnych (Taaffe, Morrill, Gould 1963, s. 505).

W dalszej części artykułu przeanalizowano historię rozwoju miejskiej sieci osadniczej Brazylii w okresie kolonialnym, starając się uwypuklić procesy i uwarunkowania, lokalne oraz międzynarodowe, pozwalające dokonać podsumowujących generalizacji wykorzystujących zaprezentowane powyżej teorie oraz modele.

\section{Początki rozwoju sieci osadniczej Brazylii}

Pierwsze portugalskie placówki w Ameryce Południowej miały służyć jedynie do celów handlowych. Nie zakładano ich w intencji stałej kolonizacji tych ziem, co było podobne do strategii stosowanej przez Portugalczyków na wybrzeżach Afryki, Indii i Dalekiego Wschodu. Pierwsze osady były prostymi faktoriami (feitorías) cechującymi się dobrym nabrzeżem do zacumowania i miejscem do magazynowania towarów przeznaczonych do handlu. Ochraniały je najczęściej palisada, fosa i budynek fortowy. Tego typu placówki militarno-handlowe były jedynymi osadami, jakie powstały na brazylijskim wybrzeżu do 1530 r. W okresie tzw. spontanicznej kolonizacji Brazylii obejmującej pierwsze 30 lat XVI w. powstało najprawdopodobniej sześć tego typu faktorii, ale jedynie dwie: Cabo Frio na wybrzeżu stanu Rio de Janeiro i Igaraçu w stanie Pernambuco, przekształciły się później w stałe osiedla (Hardoy 1978, s. 232).

Na początku lat 30. XVI w., w obliczu pojawiającej się konkurencji ze strony innych państw europejskich (głównie Francji i Holandii), Portugalia zdecydowała się na trwałą kolonizację przypadających jej w myśl traktatu z Tordesillas obszarów Ameryki Południowej. W sytuacji niewystarczających zasobów środków i ludzi, którymi dyspono- 
wał dwór królewski, a ponadto ich koncentracji na rozwoju handlu z Indiami i Azją Południowo-Wschodnią, zdecydowano się zastosować w Brazylii system kapitanii (capitanías). Polegał on na nadaniu ziemi oraz szerokich praw cywilnych i wojskowych szlachcicom pochodzącym z zamożnych rodów, zdolnym finansowo i logistycznie sprostać trudom kolonizacji nowych ziem. Brazylię podzielono na 15 równoleżnikowych pasów, ciągnących się od wybrzeża w głąb lądu, które nazwano kapitaniami i przekazano w ręce 12 „namiestników” (donatorios) (Kula 1987, Colonial Brazil... 1987).

Jednym z szeregu uprawnień, jakie otrzymywali „namiestnicy”, było prawo nadawania praw miejskich tzw. miasteczkom (vilas). Doprowadziło to do pierwszej akcji lokacyjnej miast w Brazylii obejmującej dekadę lat 30. XVI w. i związanej z tworzeniem stolic poszczególnych kapitanii. Powstało wówczas sześć miasteczek (vilas) rozrzuconych na wybrzeżu Brazylii od dzisiejszego stanu São Paulo na południu aż po stan Pernambuco na północnym wschodzie. Znalazły się wśród nich: São Vincente (1532), Porto Seguro (1535), San Jorge dos Ilheus (1536), Santa Cruz (1536), Igaraçu (1536), Olinda (1537) (rysunek 4).

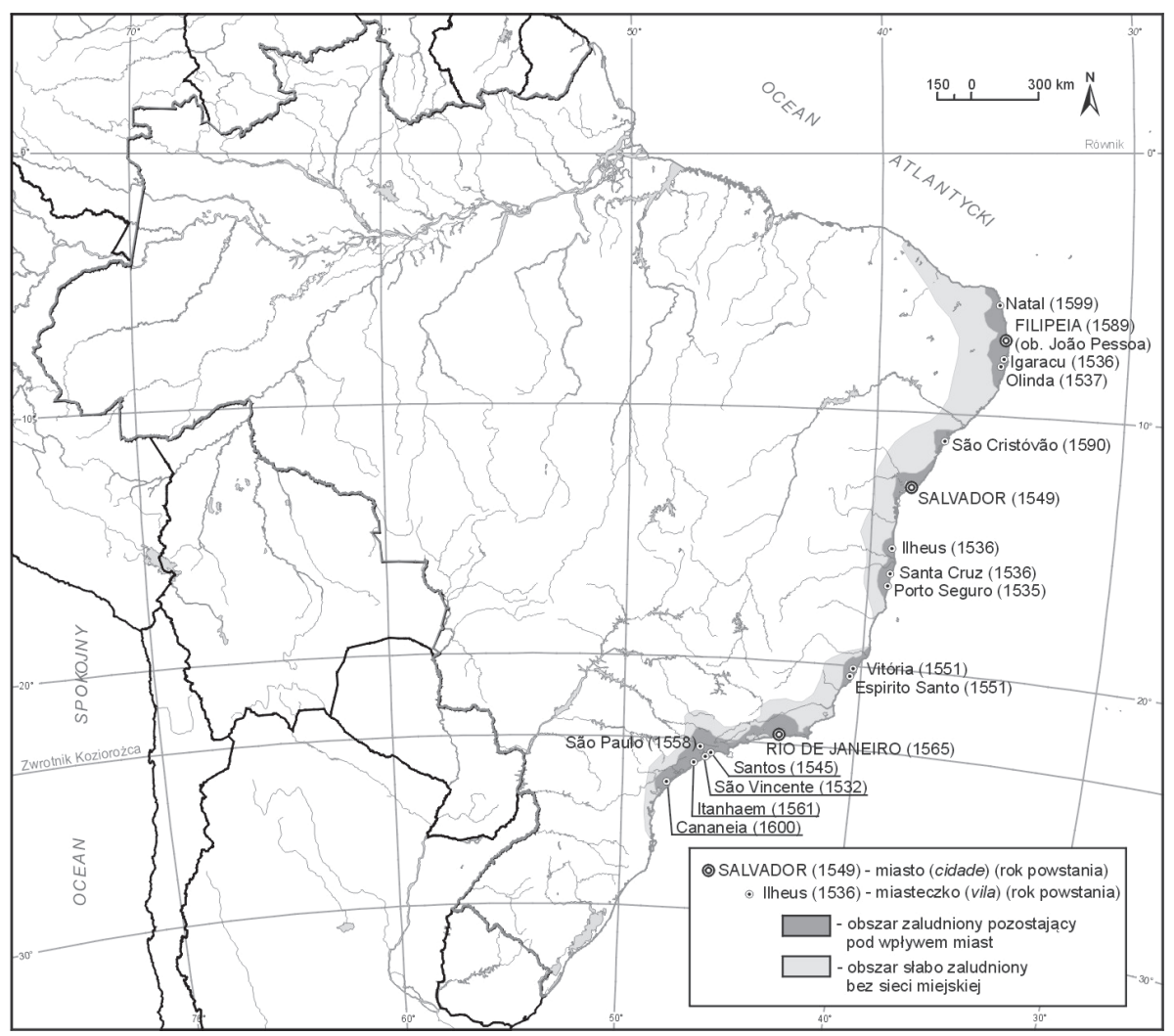

Rys. 4. Sieć miejska Brazylii w XVI w.

Źródło: opracowanie własne na podstawie: Gardner 1972, De Azevedo 1992. 
Powstające miasteczka były niewielkie, miały średniowieczne założenia urbanistyczne, najczęściej nieregularny układ ulic, niewielkie place i obronne położenie. Stąd spora ich część powstała na wzniesieniach mających naturalne warunki obronne lub dających się dobrze ufortyfikować (np. Olinda, São Paulo). Przykładem takiej lokacji jest też najstarsza część Rio de Janeiro założona w 1565 r. na wzgórzu São Januário (Castillo) otoczonym przez laguny, bagna i tereny zalewowe tworzące naturalne szańce obronne (Smith 1955, Morse 1974, Hardoy 1978).

Polityka portugalskiej korony w stosunku do Brazylii w połowie XVI w. była nastawiona na maksymalne wykorzystanie zasobów prywatnych zamożnych szlachciców i kupców, aby w jak najmniejszym stopniu zaszkodzić najbardziej dochodowemu wówczas programowi handlu z Azją. Strategia ta okazała się jednak nieskuteczna, gdyż zakładane kapitanie były zbyt słabe w walce z miejscowymi Indianami, a także francuskimi korsarzami i kolonistami. Nasilały się także spory pomiędzy „namiestnikami” poszczególnych kapitanii oraz między nimi a kolonistami. W zasadzie tylko kapitanie São Vincente i Pernambuco okazały się dochodowymi i rozwojowymi przedsięwzięciami, podczas gdy pozostałe upadły lub ledwo funkcjonowały. Zmusiło to króla Portugalii do podjęcia zdecydowanych kroków w celu centralizacji i wzmocnienia władzy na kolonizowanym wybrzeżu Brazylii. W 1548 r. wykupił on na rzecz korony kapitanię Bahia, po śmierci z rąk Indian jej „namiestnika”. W następnym roku przypłynął tu pierwszy gubernator Brazylii (Capitán-General) Tomé de Sousa. W 1549 r. w Zatoce Wszystkich Świętych (Bahia de Todos os Santos) założył on pierwsze miasto (cidade) na wybrzeżu Brazylii - Salvador da Bahia de Todos Santos, dziś nazywane po prostu Salvador (Morse 1974, Kula 1987, De Azevedo 1992).

Wraz z pierwszym gubernatorem do nowej stolicy kolonii przybyło tysiąc żołnierzy, a także rzemieślnicy, urzędnicy i pierwszych sześciu jezuitów. Najważniejszymi urzędnikami nowej kolonii, obok gubernatora, byli główny sędzia (ouvidor geral) i nadzorca podatków królewskich (provedor-mór). Z czasem Salvador stał się także siedzibą pierwszego biskupstwa (1551), a następnie arcybiskupstwa (1676) w Brazylii, co dodatkowo zwiększyło rangę i znaczenie miasta (Colonial Brazil... 1987, Kula 1987).

W latach 60. XVI w. portugalscy kolonizatorzy pod wodzą drugiego gubernatora, Mem de Sá, musieli odeprzeć próby francuskiej kolonizacji brazylijskiego wybrzeża. Na jednej z wysepek w Zatoce Guanabara Francuzi zbudowali fort Coligny. Osada ta miała być zalążkiem nowej kolonii tzw. Francji Antarktycznej, jednakże po jego zniszczeniu w 1567 r. idea ta została porzucona. Pozostałością walk w tym regionie jest drugie w Brazylii miasto zbudowane przez Portugalczyków - Rio de Janeiro. Po raz pierwszy założono je w 1565 r., jednakże zostało ono dotkliwie zrujnowane w trakcie walk i wymagało ponownej lokacji w 1567 r. (Colonial Brazil... 1987, Kula 1987).

Ostatnim miastem powstałym w XVI w. w Brazylii była Filipéia (pełna nazwa: Filipéia de Nossa Sehora das Neves) założona w 1585 r. na wybrzeżu dzisiejszego stanu Paraíba w północno-wschodniej Brazylii. W późniejszym okresie ośrodek ten zmienił nazwę na Paraíba, a współcześnie nazywa się João Pessoa i jest stolicą wspomnianego stanu (De Azevedo 1992). 
Z końcem pierwszego wieku kolonizacji brazylijska sieć miejska składała się z trzech miast, spośród których największym i najważniejszym ośrodkiem był Salvador. Ponadto sieć uzupełniało 14 miasteczek (vilas) zlokalizowanych głównie wzdłuż południowo-wschodniego i północno-wschodniego wybrzeża Brazylii. Jedynym miasteczkiem położonym głębiej w interiorze było założone w 1558 r. São Paulo (São Paulo de Piratininga). Leżało ono na płaskowyżu na wysokości ok. 700 m n.p.m. po zachodniej stronie gór Serra do Mar w odległości około 70 km od atlantyckiego wybrzeża. Pozostałe ośrodki były typowymi nadmorskimi miastami tworzącymi przyczółki kolonizacyjne na wybrzeżu brazylijskim. Komunikacja między nimi odbywała się głównie drogą morską, gdyż szlaki lądowe były słabo rozwinięte (De Azevedo 1992, Morse 1978).

Na koniec XVI w. największą liczbą ośrodków miejskich legitymował się dzisiejszy stan São Paulo (a wówczas kapitania São Vincente), w którym znajdowało się 5 miasteczek (vilas). Na kolejnym miejscu znajdował się dzisiejszy stan Bahia z jednym miastem (cidade) i 3 miasteczkami. W hierarchii ośrodków dominował zdecydowanie Salvador, na kolejnej pozycji znajdowało się Rio de Janeiro - najważniejszy ośrodek południowo-wschodniej części wybrzeża, a następnie Filipéia - dominująca nad północno-wschodnim cyplem Brazylii. Wśród miasteczek szczególnie wyróżniała się Olinda - stolica najprężniej wówczas prosperującej kapitanii Pernambuco (rysunek 4, tabela 1).

Tabela 1

Zmiany liczby lokacji miast (cidades) i miasteczek (vilas) w Brazylii w okresie kolonialnym 1532-1822

\begin{tabular}{|c|c|c|c|c|c|c|c|c|c|}
\hline \multirow[b]{2}{*}{ Regiony i stany } & \multicolumn{4}{|c|}{ Miasta (cidades) } & \multicolumn{5}{|c|}{ Miasteczka (vilas) } \\
\hline & XVI w. & XVII w. & XVIII w. & $\begin{array}{c}1801- \\
1822\end{array}$ & XVI w. & XVII w. & XVIII w. & $\begin{array}{c}1801- \\
1822\end{array}$ & Łącznie \\
\hline Północny & & 1 & & & & 3 & 17 & & 20 \\
\hline Acre & & & & & & & & & 0 \\
\hline Amapa & & & & & & & 1 & & 1 \\
\hline Amazonas & & & & & & & 8 & & 8 \\
\hline Para & & 1 & & & & 3 & 8 & & 11 \\
\hline Rondonia & & & & & & & & & 0 \\
\hline Roraima & & & & & & & & & 0 \\
\hline Tocantins & & & & & & & & & 0 \\
\hline Północno-wschodni & 2 & 2 & 1 & & 7 & 13 & 58 & 22 & 100 \\
\hline Alagoas & & & & & & 3 & 2 & 3 & 8 \\
\hline Bahia & 1 & & & & 3 & 5 & 27 & 5 & 40 \\
\hline Ceara & & & & & & 1 & 13 & 4 & 18 \\
\hline Maranhão & & 1 & & & & 1 & 3 & 3 & 7 \\
\hline Paraíba & 1 & & & & & & 4 & 1 & 5 \\
\hline Pernambuco & & 1 & & & 2 & 1 & 1 & 6 & 10 \\
\hline
\end{tabular}


Tabela $1 \mathrm{~cd}$

\begin{tabular}{|c|c|c|c|c|c|c|c|c|c|}
\hline \multirow[b]{2}{*}{ Regiony i stany } & \multicolumn{4}{|c|}{ Miasta (cidades) } & \multicolumn{5}{|c|}{ Miasteczka (vilas) } \\
\hline & XVI w. & XVII w. & XVIII w. & $\begin{array}{c}1801- \\
1822\end{array}$ & XVI w. & XVII w. & XVIII w. & $\begin{array}{c}1801- \\
1822\end{array}$ & Łącznie \\
\hline Piaui & & & 1 & & & & 2 & & 2 \\
\hline Rio Grande do Norte & & & & & 1 & & 3 & & 4 \\
\hline Sergipe & & & & & 1 & 2 & 3 & & 6 \\
\hline Południowo-wschodni & 1 & 1 & 2 & & 7 & 18 & 31 & 14 & 70 \\
\hline Espirito Santo & & & & & 2 & 1 & 2 & 1 & 6 \\
\hline Minas Gerais & & & 1 & & & & 14 & 2 & 16 \\
\hline Rio de Janeiro & 1 & 1 & & & & 6 & 2 & 9 & 17 \\
\hline São Paulo & & & 1 & & 5 & 11 & 13 & 2 & 31 \\
\hline Południowy & & & & & & 3 & 7 & 6 & 16 \\
\hline Parana & & & & & & 2 & 3 & 1 & 6 \\
\hline Santa Catarina & & & & & & 1 & 3 & & 4 \\
\hline Rio Grande do Sul & & & & & & & 1 & 5 & 6 \\
\hline Centralno-zachodni & & & & 2 & & & 5 & 2 & 7 \\
\hline Dystrykt Federalny & & & & & & & & & 0 \\
\hline Goias & & & & 1 & & & 1 & 1 & 2 \\
\hline Mato Grosso & & & & 1 & & & 4 & 1 & 5 \\
\hline Mato Grosso do Sul & & & & & & & & & 0 \\
\hline Łącznie & 3 & 4 & 3 & 2 & 14 & 37 & 118 & 44 & 213 \\
\hline
\end{tabular}

Źródło: Opracowanie własne na podstawie: Gardner 1972, De Azevedo 1992.

\section{Rozwój osadnictwa miejskiego w Brazylii w XVII w.}

Na początku XVII w. portugalskie osadnictwo przesuwa się w kierunku północnym, blokując próby francuskiej kolonizacji w regionie ujścia Amazonki. Powstają wówczas dwa miasta: São Luis do Maranhão, założone w 1612 r. przez Francuzów pod wodzą Daniela de la Touche podczas nieudanej próby utworzenia kolonii „Francji Równikowej”, oraz Belem (Nossa Senhora de Belém), utworzone w 1616 r. zaraz po wypędzeniu Francuzów z Maranhão. Belem pełniło rolę fortecy broniącej dostępu do dorzecza Amazonki i było zarazem stolicą kapitanii Para. Francuzi zagrażający portugalskiemu panowaniu nad tymi obszarami od strony Gujany zmusili Portugalię do skolonizowania i umocnienia ujścia Amazonki (De Azevedo 1992). Jednakże intensywniejsza akcja osadnicza w dorzeczu Amazonki zaczęła się dopiero w drugiej połowie XVIII w. Ciekawym przykładem jest miasto-twierdza Mazagan na wybrzeżu marokańskim, które w 1769 r. zostało ewakuowane i przeniesione na lewy brzeg Amazonki, na zachód od założonego wcześniej miasteczka Macapá (Vidal 2008). 
W XVII w. status miasta uzyskały jeszcze: dawna faktoria Cabo Frio podniesiona do rangi miasta w 1615 r. oraz Olinda, która uzyskała prawa miejskie w 1676 r. dla upamiętnienia jej roli jako „komórki macierzystej” (célula mater) osadnictwa miejskiego w strefie cukrowniczej Pernambuco. Ponadto starano się zaktywizować rozwój tego podupadłego ośrodka, który został silnie zniszczony w trakcie walk z Holendrami. Pamiątką holenderskiej obecności na północno-wschodnim wybrzeżu Brazylii w latach 1630-1654 było portowe miasto Recife wyrosłe w sąsiedztwie Olindy i cieszące się szybszym od niej tempem rozwoju (De Azevedo 1992).

Unia dynastyczna Hiszpanii i Portugalii w latach 1580-1640 wyraźnie osłabiła sytuację kolonii portugalskich w Ameryce Południowej i zachęciła Holandię do przejęcia kontroli nad najbardziej dochodowymi kapitaniami cukrowymi północnego wschodu. Pierwsze zajęcie przez Holendrów Salwadoru w 1624 r. skończyło się klęską - wypędzeniem ich z miasta w następnym roku. W 1630 r. zajęli oni jednak równie bogatą, a słabiej ufortyfikowaną niż stolica kapitanię Pernambuco. Przeciągający się konflikt przerodził się w długotrwałą wojnę partyzancką toczoną z różną intensywnością. Odzyskanie przez Portugalię niezależności od Hiszpanii w 1640 r. w połączeniu ze zmniejszeniem przez holenderską Kompanię Indii Zachodnich załogi w Brazylii i rezygnację Maurycego de Nassau z funkcji gubernatora holenderskich terenów przyspieszyło wybuch powstania w 1645 r., które doprowadziło do odzyskania przez portugalskich kolonistów większości obszaru, a panowanie Holendrów ograniczało się jedynie do miasta Recife. Kolejne lata nie przynosiły jednak ostatecznego rozstrzygnięcia, choć w Holandii słabło poparcie dla brazylijskiej kolonii. Sytuacja uległa zmianie w 1652 r. - wraz z wybuchem wojny angielsko-holenderskiej Portugalia uzyskała przewagę i doprowadziła do kapitulacji załogi Recife oraz wycofania się Holendrów z Brazylii (Colonial Brazil... 1987, Kula 1987). Widocznym śladem holenderskiej obecności w Brazylii było dobrze ufortyfikowane miasto portowe - Mauritsstad (nazywane też Mauricia) wybudowane obok Recife i współcześnie będące jego częścią (Castro 1957).

Miejska sieć osadnicza w XVII w. nadal rozwijała się głównie wzdłuż wybrzeża, co doprowadziło do wyraźnego zagęszczenia liczby miasteczek widocznego w dwóch jego częściach: w części północno-wschodniej pomiędzy miastami Paraiba i Ilheus oraz w części południowo-wschodniej od miasta Vitória aż po São Francisco do Sul w obecnym stanie Santa Catarina. Potwierdzało to już ukształtowany we wcześniejszym stuleciu podział na dwa centra gospodarcze - jedno skupione wokół Olindy i Salvadoru i oparte na gospodarce cukrowej, a drugie, bardziej zróżnicowane gospodarczo, rozciągało się między São Paulo i Rio de Janeiro. Poza tymi dwoma obszarami sieć miejska wykształciła się jeszcze w centrum kapitanii Para (região paraense) i kapitanii Maranhão (região maranhense) (rysunek 5). Generalnie rzecz biorąc, wybrzeże Brazylii od ujścia Tapajós aż po wyspę São Francisco w Santa Catarina pokryło się siecią miast i miasteczek na długości dwa razy dłuższej w porównaniu do sytuacji z końca XVI w. (Gardner 1972, De Azevedo 1992).

Warto również podkreślić, iż postępowała także penetracja dalszych terenów i kolonizacja Wyżyny Brazylijskiej. São Paulo przestało być jedynym ośrodkiem na tym 
obszarze, osadnictwo przesunęło się dalej na południowy zachód w kierunku Płaskowyżu Centralnego (Planalto Central) oraz na południe, sięgając Płaskowyżu Kurytyby (Planalto de Curitiba). Nowe miasteczka pojawiły się też w środkowej części doliny Paraiby do Sul na drodze wykorzystywanej przez bandeirantes udających się w głąb Minas Gerais. Nowo powstałe na obszarach wyżynnych ośrodki pełniły rolę bram do interioru (bocas de sertão) i można je uznać za klasyczne przykłady miast-bram (gateway cities) związanych z przesuwaniem granicy zasięgu kolonizacji (Simmons 1983). W grupie tej znalazły się m.in.: Kurytyba, Sorocaba, Itú, Jundiaí, Guaratinguetá oraz Cametá pełniąca podobną rolę w przypadku Amazonii (rysunek 5).

Pod koniec XVII w. najliczniejszą siecią miejską charakteryzował się stan São Paulo, w którym zlokalizowanych było 16 spośród 58 założonych dotychczas miast i miasteczek. Na kolejnym miejscu znajdował się obszar obecnego stanu Bahia z dziewięcioma ośrodkami, a trzecią pozycję zajmował stan Rio de Janeiro z ośmioma tego typu osiedlami (tabela 1). Te trzy stany tworzyły zarazem główne centra osadnicze i gospodarcze

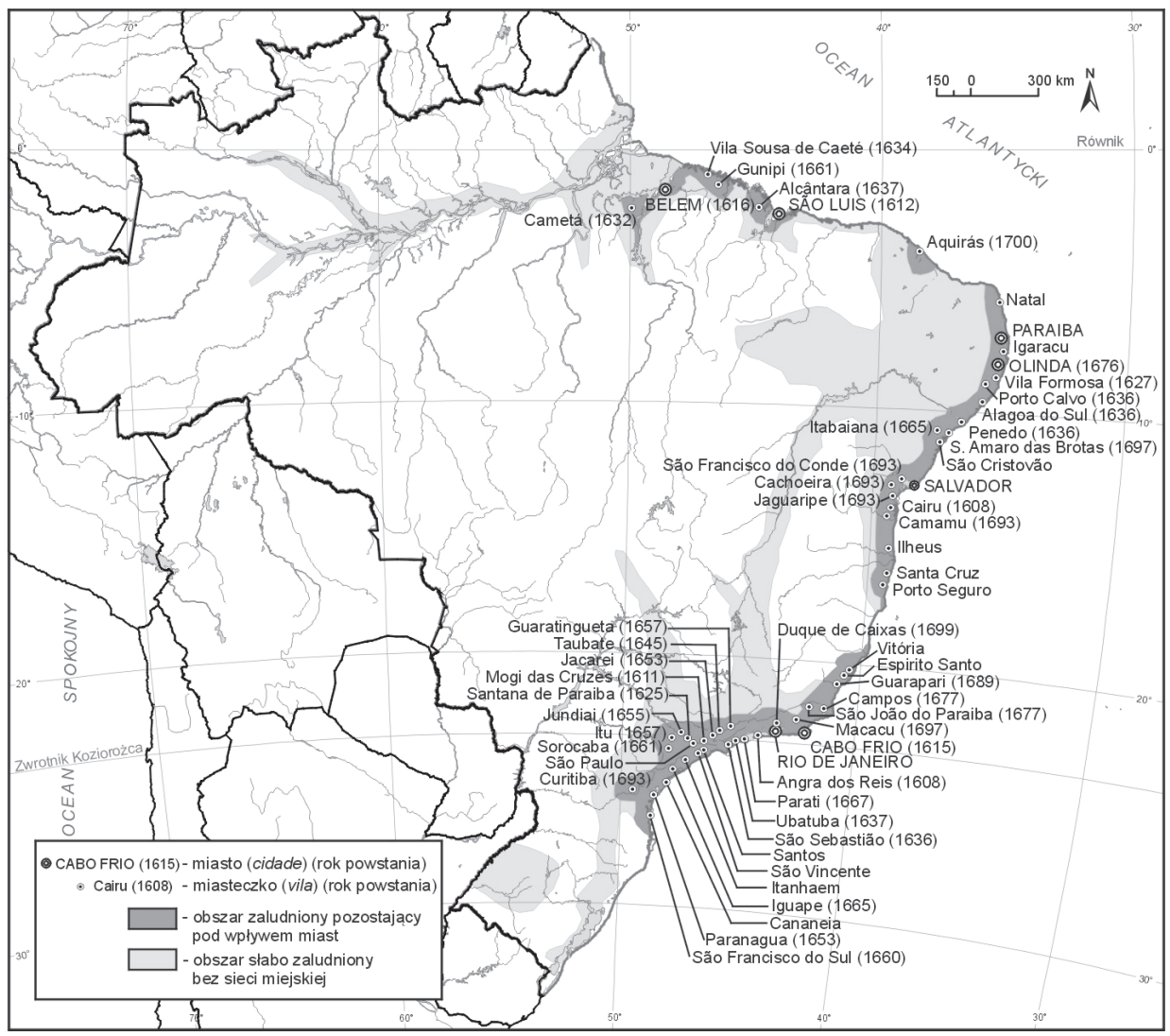

Rys. 5. Sieć miejska Brazylii w XVII w.

Źródło: Opracowanie własne na podstawie: Gardner 1972, De Azevedo 1992. 
umacniającej się portugalskiej kolonii, której w tym wieku udało się skutecznie odeprzeć zarówno francuskie, jak i o wiele groźniejsze - holenderskie - próby zdobycia panowania nad częściami brazylijskiego wybrzeża. Głównym ośrodkiem pozostawała stolica - Salvador licząca pod koniec wieku ok. 8 tys. białych mieszkańców oraz kilkanaście tys. Murzynów i Indian. Zarejestrowano w nim ok. 2 tys. domów mieszkalnych i 12 dużych kościołów (Mauro 1978, De Azevedo 1992).

\section{Rozwój osadnictwa miejskiego w Brazylii w XVIII w.}

W porównaniu z dwoma wcześniejszymi stuleciami w XVIII w. doszło do znaczących przemian krajobrazu miejskiego Brazylii. Proces urbanizacji uwolnił się już na dobre od atlantyckiego wybrzeża, przesuwając się zarówno w głąb Wyżyny Brazylijskiej aż po Mato Grosso, jak również w głąb Niziny Amazonki. Miejskie osadnictwo pojawiło się także na zapleczu plantacji cukrowych północnego wschodu, pojawiając się na obszarach hodowli bydła nad środkowym biegiem rzeki São Francisco i na suchych sawannach (sertão) Ceary, gdzie w 1761 r. powstało miasto Oeiras w miejsce wcześniejszej osady Vila do Mocha, będącej centrum olbrzymiego latyfundium hodowlanego (rysunek 6). O ile kolonizacja miejska interioru Wyżyny Brazylijskiej związana była głównie z „gorączką złota”, a następnie diamentów, to w przypadku doliny Amazonki oraz południowych krańców Brazylii była ona głównie wynikiem działalności misjonarzy oraz rozbudową fortów wojskowych na rubieżach rozrastającej się kolonii (Gardner 1972, Morse 1974, Schwartz 1987, De Azevedo 1992).

Odkrycie w ostatnich latach XVII w. aluwialnych pokładów złota na obszarze obecnego stanu Minas Gerais wywołało szybkie przyspieszenie penetracji i kolonizacji Wyżyny Brazylijskiej, co wiązało się też z aktywną akcją lokacyjną nowych ośrodków miejskich. Trwający do lat 60. XVIII w. cykl gospodarki górniczej wywołał również masową migrację z Portugalii do Brazylii, diametralnie zmieniającą liczbę i strukturę rasową ludności kolonii. Według szacunków Celso Furtado w 1700 r. biała ludność Brazylii wynosiła jedynie ok. 100 tys. osób, natomiast w 1800 r. nieznacznie przekroczyła $1 \mathrm{mln}$, co wskazuje, iż napływ migracyjny z metropolii musiał być nie mniejszy niż 300 tys., a według niektórych badaczy mógł osiągnąć nawet ok. pół mln osób. Jak zauważa Furtado, napływ ten był wyższy niż migracja z Hiszpanii do wszystkich jej kolonii w Ameryce Łacińskiej w całym okresie kolonialnym (Furtado 1967, s. 111).

Tak duży napływ migracyjny z Portugalii do obszarów złotonośnych w połączeniu z wewnętrznym odpływem ludności z podupadającej w ostatnich dekadach XVII w. gospodarki cukrowej był czynnikiem przyspieszającym osadnictwo miejskie na obszarach górniczych. Warto jednak podkreślić, iż w związku z faktem, że odkryte złoża złota były w większości aluwialnego pochodzenia, o bardzo zróżnicowanej zawartości cennego kruszcu, i znacznie miej sprzyjały tworzeniu się trwałych ośrodków miejsko-górniczych niż w przypadku odkrytych przez Hiszpanów złóż srebra w środkowym Meksyku i Peru. W przypadku brazylijskich ośrodków górniczych wypłukiwacze złota 


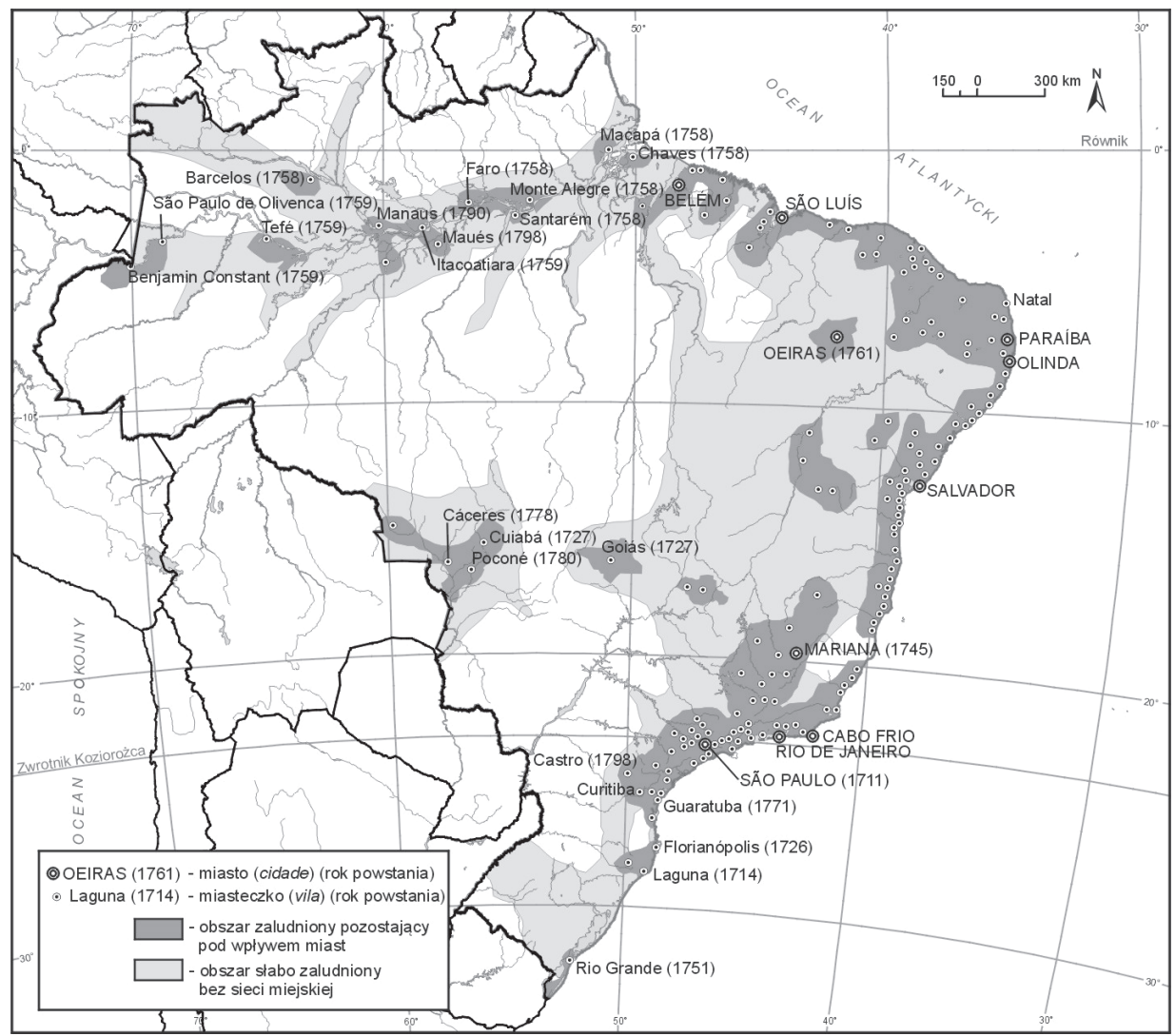

Rys. 6. Sieć miejska Brazylii w XVIII w.

Źródło: Opracowanie własne na podstawie: Gardner 1972, De Azevedo 1992.

(faiscadores) zakładali najpierw skromne obozowisko (arraial) - najczęściej u podnóża stoku powyżej miejsca zbiegu dwóch rzek. Zwykle składało się ono z kilku lub kilkunastu szałasów otoczonych małymi poletkami kukurydzy, fasoli lub manioku. Jeżeli złoże ulegało szybkiemu wyczerpaniu, osada znikała tak samo szybko, jak powstała, jeżeli jednak było wystarczająco zasobne, mogła się z czasem przekształcić w jednoulicową wioskę. Fizjonomia tego typu osad była najczęściej bardzo podobna. Dominujące znaczenie odgrywała w nich kaplica z położonym przed nią placem, umiejscowione najczęściej w dominującym nad doliną wypłaszczonym wzniesieniu, od której odchodziła ulica biegnąca po zboczu aż do rzeki z zabudowaniami po obu stronach. Jeżeli trafiono na szczególnie bogate złoża bądź żyły złota wymagające długotrwałej eksploatacji przy zastosowaniu bardziej zaawansowanych narzędzi, powstawały latyfundia górnicze prowadzące w konsekwencji do powstania trwałych ośrodków miejskich (Mauro 1978, s. 263).

W obecnym stanie Minas Gerais w wyniku gorączki złota i związanej z nim akcji osadniczej powstało w XVIII w. 14 miasteczek (vilas) oraz miasto Mariana, założone 
w 1745 r. i będące pierwszą stolicą kapitanii Minas Gerais, która następnie została przeniesiona do Ouro Preto (Morse 1974, Mauro 1978). Bardzo intensywna akcja lokacyjna nowych miast zachodziła także w regionie północno-wschodnim, w którym utworzono wówczas aż 58 vilas i jedno miasto. Na szczególną uwagę zasługuje stan Bahia, na obszarze którego powstało aż 27 miasteczek, z których kilkanaście ulokowano z dala od wybrzeża na obszarach hodowli bydła, które do tej pory charakteryzowały się brakiem wykształconych miejskich form osadniczych. Podobną sytuację, choć na znacznie mniejszą skalę, zaobserwowano w przypadku kapitanii Ceara, w której powstało 13 miasteczek i jedno miasto (tabela 1, rysunek 6).

Aktywną akcję osadniczą prowadzono również na terenie obecnego stanu São Paulo, w którym powstało 13 nowych miasteczek, a São Paulo w 1711 r. zostało podniesione do rangi miasta (cidade) (tabela 1). Kolonizacja miejska posuwała się dalej w głąb płaskowyżu oraz w kierunku południowym wraz z rozwojem hodowli i zakładaniem fortów wojskowych na południowych krańcach wybrzeża. Ambicją Portugalczyków w tym okresie było opanowanie na południu ujścia La Platy i terytorium współczesnego Urugwaju, jednakże nie skończyło się ono sukcesem (Colonial Brazil... 1987, Kula 1987). Rozwój hodowli bydła i mułów na obszarach od Parany aż po Rio Grande do Sul przyczynił się do powstania sieci miast na trasach przepędzania stad z południowych pastwisk na miejsca ich sprzedaży na obszarach górniczych (Morse 1974, 1978).

Czwartym obszarem intensywnej aktywności lokacyjnej miast było w tym stuleciu dorzecze Amazonki. Jakkolwiek obszar ujściowy został już opanowany w poprzednim stuleciu, a założone w 1616 r. Belem rozrosło się, pełniąc rolę stolicy kapitanii Pará, to jednak dopiero w XVIII w. miejskie osadnictwo europejskie wkroczyło w głąb Amazonii. Duże zasługi w tym miała polityka pełniącego od 1750 r. funkcję pierwszego ministra na dworze królewskim José de Carvalho e Melo markiza de Pombal. Starał się on prowadzić politykę zmierzającą do rozwoju w Pará i Maranhão upraw ryżu, kakao i bawełny, które byłyby towarami eksportowymi zapewniającymi ekonomiczny byt tym kapitaniom i finansującymi dalszą kolonizację tego obszaru. Osadnictwo w dorzeczu Amazonki było napędzane przez dwa główne procesy. Pierwszym z nich była akcja misyjna różnych zakonów wśród ludności indiańskiej, zmierzająca do stworzenia stałych osad, które z czasem przekształcały się w parafie (freguesias), a te z kolei wraz z pojawieniem się białych osadników mogły się przekształcić w vilas. Drugim ważnym procesem była rozbudowa fortów i osad garnizonowych stanowiąca forpocztę kolonizacji i obronę przez obcymi kolonistami zagrażającymi z rejonu Gujan. W wyniku współdziałania tych dwóch sił w drugiej połowie XVIII w. udało się opanować rozległe obszary doliny Amazonki i jej głównych dopływów. Na obszarze obecnych stanów Amazonas i Pará założono wówczas po osiem miasteczek, a szczególnie intensywna była akcja lokacyjna w latach 50. XVIII w., kiedy to powstało aż 15 vilas. Połowa XVIII w. była szczególnie aktywnym okresem tworzenia nowych miast. W dekadzie lat 50. powstało ich aż 36 , a w dekadzie lat 60. jeszcze 16. W kolejnych dwóch dekadach liczebność nowo powstających ośrodków znacznie spadła, co było związane z wyczerpywaniem się złóż złota i diamentów, niemniej jednak w wyniku reorganizacji gospodarki związanej z końcem 
tzw. gorączki złota doszło również do przemian w sieci osadniczej, skutkujących dalszym przyrostem liczby nowych ośrodków miejskich (rysunki 6 i 7).

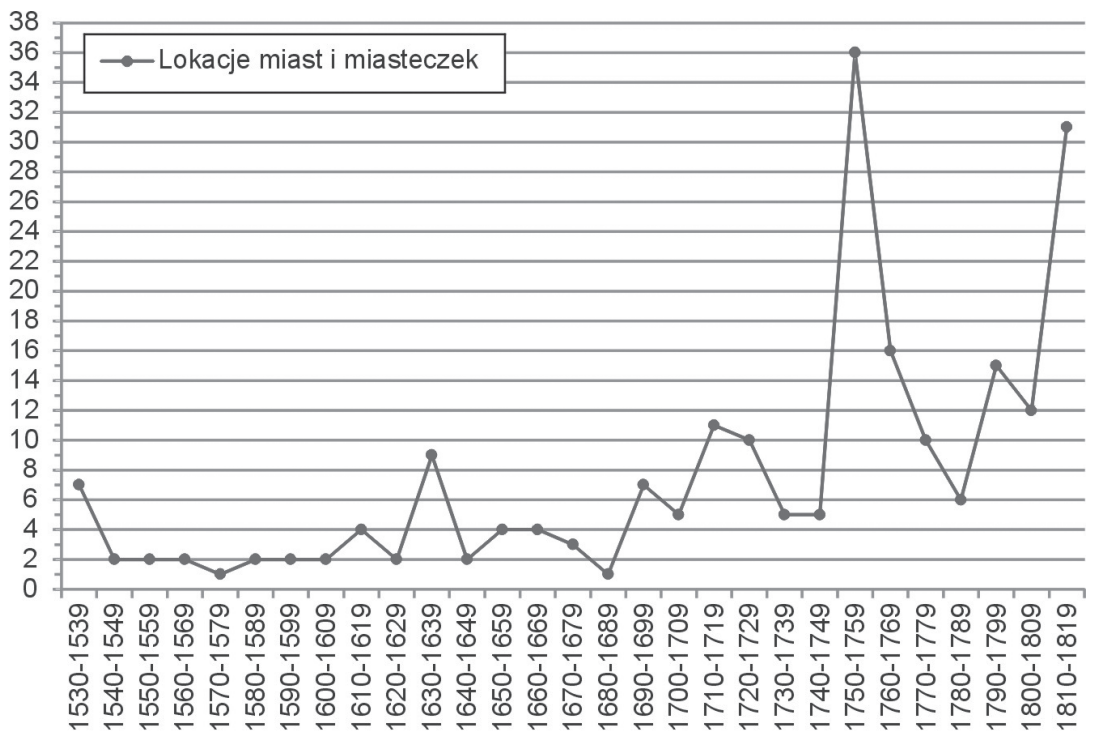

Rys. 7. Zmiany liczby nowych lokacji miast (cidades) i miasteczek (vilas) w Brazylii w okresie kolonialnym (1530-1819)

Źródło: Opracowanie własne na podstawie: De Azavedo 1992, Morse 1974.

W XVIII w. powstało aż 118 nowych ośrodków miejskich, a trzy wcześniej istniejące miasteczka uzyskały status miast (São Paulo, Mariana, Oeiras). W tym stuleciu doszło do znaczącego rozprzestrzenienia się osadnictwa miejskiego zarówno w Amazonii, jak i w kierunku ujścia La Platy oraz w głąb interioru. Rozszerzenie terytorium Brazylii było w dużej mierze zasługą i wynikiem penetracji interioru przez bandeirantes oraz poszukiwaczy złota, jednakże dopiero podpisany w 1750 r. w Madrycie traktat sankcjonował powiększenie portugalskiej kolonii i zastępował de facto traktat z Tordesillas. Hamował on także dalszą portugalską ekspansję na kontynencie i pomimo wielu korekt granic dokonanych w późniejszym okresie stał się podstawą współczesnych granic Brazylii. Ustalenia traktatu madryckiego były dla Portugalii impulsem do zaktywizowania akcji kolonizacyjnej w Amazonii, na południowych krańcach wybrzeża atlantyckiego oraz w Goiás i Mato Grosso, stąd większość ośrodków miejskich w tych obszarach została założona w drugiej połowie XVIII w. (Kula 1987, Silva 1987, De Azevedo 1992).

Warto również podkreślić, że wraz z rozwojem górnictwa złota i kamieni szlachetnych wzrosło w Brazylii zapotrzebowanie na narzędzia niezbędne do eksploatacji oraz na dobra konsumpcyjne i żywność, co było podstawą do początków rozwoju pierwszych manufaktur przemysłowych. Ludność miast i miasteczek Minas Gerais była pierwszą tego typu grupą społeczną, wystarczająco liczną, aby stworzyć możliwości 
samonapędzającego się wzrostu gospodarczego głównie w przemyśle tekstylnym i metalowym. Były one jednak hamowane przez politykę Portugalii, która czerpała zyski $\mathrm{z}$ pośrednictwa $\mathrm{w}$ handlu z kolonią, sama również nie rozwijając własnego przemysłu. Wynikało to z niekorzystnych ustaleń podpisanego w 1703 r. traktatu z Anglią, tzw. traktatu Methuena, który w dłuższej perspektywie przyczynił się do upadku rodzącego się w Portugalii i Brazylii przemysłu. Traktat ten gwarantował angielskim towarom uprzywilejowany dostęp do portugalskiego, a także brazylijskiego rynku, a ich konkurencja doprowadziła do upadku rodzimych producentów (Furtado 1967). Dodatkowo jeszcze w przypadku Brazylii królowa Maria I wydała w 1785 r. zarządzenie nakazujące zamknięcie funkcjonujących w kolonii manufaktur i skupienie się na produkcji rolniczej i wydobyciu złota. Na szczęście jednak dla brazylijskich zakładów przepis ten nie obowiązywał wystarczająco długo, by wyrządzić większe szkody, gdyż po odsunięciu od władzy psychicznie chorej królowej jej syn Jan, który został regentem, cofnął to zarządzenie, a urzędujący wówczas w Brazylii gubernator Luis Pinto de Sousa w 1795 r. ponownie zezwolił na działalność manufaktur (Rogers 1962).

Rozwój górnictwa złota przyczynił się również do ważnych zmian w hierarchii ośrodków miejskich w Brazylii. Najbardziej widocznym jej przejawem jest przeniesienie w 1763 r. stolicy wicekrólestwa z Salvadoru do Rio de Janeiro, które stało się głównym portem wywozu złota oraz dostaw towarów konsumpcyjnych. Biorąc pod uwagę fakt, iż główne zyski władz kolonii były czerpane z opodatkowania handlu międzynarodowego, to w sytuacji gdy spadło znaczenie eksportu cukru na korzyść złota, w zamian za które napływały importowane towary, kontrola nad ich przeładunkiem w porcie Rio de Janeiro gwarantowała wpływy do budżetu wicekrólestwa (Furtado 1967, Silva 1987). Zmieniła się też regionalna hierarchia miejskich systemów osadniczych, gdyż na pierwsze miejsce wysunął się obszar górniczy Minas Gerais, a na kolejnych znalazły się regiony: São Paulo, Rio de Janeiro, Bahia, Recife, a w dalszej kolejności Belem i São Luis do Maranhão (Mauro 1978, De Azevedo 1992). Wskazuje to na wyraźne przesunięcie się na południowy wschód gospodarczego i osadniczego środka ciężkości kolonii, a wykształcony wówczas trójką dominujących kapitanii Minas Gerais - São Paulo - Rio de Janeiro pozostaje dominujący w hierarchii brazylijskiej sieci miejskiej i gospodarce po dziś (Deák, Schiffer 2007).

\section{Rozwój osadnictwa miejskiego Brazylii w pierwszym dwudziestoleciu XIX w.}

Ostatni etap kolonialnego rozwoju sieci miejskiej Brazylii obejmuje pierwsze 22 lata XIX w. W okresie tym powstały dwa miasta (cidades) oraz 44 miasteczka (vilas), co sprawiło, iż w momencie uzyskania niepodległości łączna liczba miast sięgnęła 12, a miasteczek 213 (tabela 1). Oba nowe ośrodki powstały w 1818 r. i znajdowały się w głębi interioru w regionie centralno-zachodnim (Região Centro-Oeste). Pierwsze z nich - Cuiabá - powstało z przekształcenia dawnego miasteczka Vila Real w Senhor 
Bom Jesus, następnie w Cuiabá. Ze względu na lepsze położenie geograficzne zdystansowało ono wcześniejszą stolicę kapitanii Mato Grosso - Vila Bela i przejęło jej funkcje. Drugie powstałe miasto to Goiás (wcześniejsza Vila Boa), będące stolicą kapitanii Goiás, rozwinięte w okresie gorączki złota. Funkcje stołeczne pełniło ono przez niecały wiek, tracąc je w 1937 r. na rzecz nowo powstałego miasta - Goiânia, mającego zdecydowanie lepsze położenie i możliwości rozwoju przestrzennego (De Azevedo 1992). Rozwój tych ośrodków odpowiadał charakterystycznej dla tego okresu tendencji do zakładania miast w interiorze oraz zagospodarowywania południowych krańców Brazylii. Szczególnie dużo nowych miasteczek powstało wówczas w stanie Rio Grande do Sul wraz z rozwojem gospodarki hodowlanej bydła i mułów (rysunek 8 ).

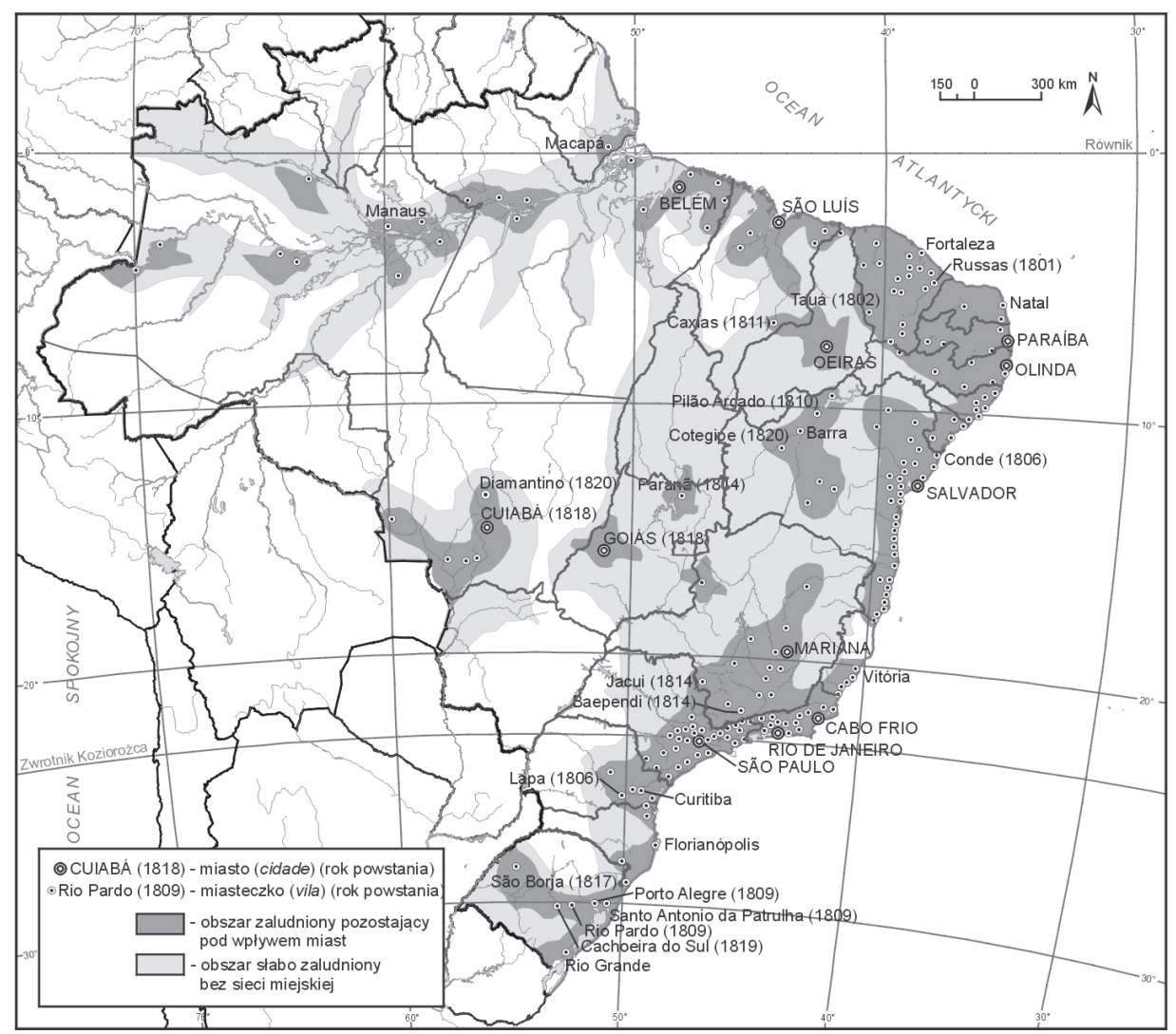

Rys. 8. Sieć miejska Brazylii w 1822 r.

Źródło: Opracowanie własne na podstawie: Gardner 1972, De Azevedo 1992.

Muły były głównymi zwierzętami wykorzystywanymi w transporcie na szlakach łączących interior z portami wybrzeża, natomiast bydło hodowano zarówno w celach pociągowych, jak i dla produkcji mięsa. Po wielkiej suszy, która w latach 1793-1794 
dotknęła interior regionu północno-wschodniego, doprowadzając do śmierci większość pogłowia, gwałtownie wzrósł popyt na nie, doprowadzając do rozwoju hodowli na znacznie bogatszych pastwiskach Rio Grande do Sul. Przemysłowy przerób mięsa był natomiast ważnym czynnikiem miastotwórczym w tym stanie. Produkowane suszone i solone mięso wołowe (charque) było podstawą wyżywienia niewolniczej siły roboczej na plantacjach, a także uboższych mieszkańców miast, co zapewniało mu stosunkowo chłonny rynek zbytu. Zakładanie i rozbudowa zakładów produkcyjnych, tzw. charqueadas, były jednym z ważniejszych czynników rozwoju miasteczek portowych Rio Grande do Sul (Leitman 1978).

Ważnym czynnikiem przyspieszającym proces urbanizacji Brazylii była ucieczka przed wojskami Napoleona dworu królewskiego z Lizbony do Rio de Janeiro. W 1808 r. flota królewska z księciem regentem Janem oraz dworem szacowanym na 8-15 tys. dworzan i urzędników dotarła pod osłoną angielskiej marynarki do Brazylii. Podpisane traktaty warunkujące angielską pomoc doprowadziły do pogłębienia uzależnienia Portugalii, a pośrednio także Brazylii, od Anglii. Jednakże z perspektywy brazylijskiej było to ważnym impulsem rozwojowym, gdyż regent Jan zaraz po przybyciu zezwolił na rozwój manufaktur, a jego polityka szczególnie wspierała rozwój przemysłu hutniczego i metalowego. Wraz z dworem do Brazylii dotarło wielu specjalistów oraz zamożnej arystokracji, co przyczyniło się do zwiększenia rynku wewnętrznego oraz rozwoju działalności przemysłowej (Rogers 1962, Furtado 1967, Kula 1987).

Szczególnie silny impuls rozwojowy uzyskało Rio de Janeiro, stając się w tej sytuacji stolicą portugalskiego imperium. Pojawienie się w mieście dworu królewskiego doprowadziło do jego szybkiej rozbudowy. Główne zmiany dotyczyły rozwoju sieci wodno-kanalizacyjnej, powstała też pierwsza drukarnia oraz liczne uczelnie: Szkoła Medycyny, Szkoła Sztuk Pięknych, Szkoła Wojskowa, Szkoła Marynarki, Szkoła Artylerii, założono również Bibliotekę Królewską, szpital wojskowy i ogród botaniczny. Z punktu widzenia rozwoju gospodarczego ważnymi krokami były powołanie Banku Brazylijskiego oraz gwałtowny wzrost obrotów handlowych obsługiwanych w porcie Rio de Janeiro (Kula 1987, Skidmore 1999). Zmiany te przełożyły się na gwałtowny rozwój zaludnienia miasta, które w momencie przybycia dworu królewskiego liczyło ok. 65 tys. mieszkańców, a do roku 1819 zwiększyło się o blisko 3/4 - do ok. 113 tys. (tabela 2).

W grudniu 1815 r. książę regent Jan proklamował utworzenie Królestwa Brazylii, a w kolejnym roku, po śmierci matki - królowej Marii I, koronował się na króla Jana VI (João VI), panującego nad Zjednoczonym Królestwem Portugalii, Brazylii i Algarve. Pod koniec drugiej dekady XIX w. nasilały się naciski z Portugalii wzywające króla do powrotu, jednakże on zwlekał z podjęciem tej decyzji. W 1820 r. wybuchły w Portugalii zamieszki przeciwko absolutnej władzy królewskiej. Powołano kortezy mające przygotować konstytucję, którą król zaaprobował w lutym 1821 r., a w kwietniu wypłynął w podróż do Portugalii, zostawiając w Brazylii swojego syna Piotra jako regenta. W kolejnych miesiącach doszło do wzrostu napięcia między Portugalią i Brazylią, co zmusiło panującego regenta do dokonania wyboru pomiędzy powrotem do Lizbony 
Zmiany zaludnienia głównych miast Brazylii pod koniec okresu kolonialnego

\begin{tabular}{|c|c|c|c|c|c|}
\hline Miasto & Rok & $\begin{array}{c}\text { Liczba } \\
\text { mieszkańców }\end{array}$ & Miasto & Rok & $\begin{array}{c}\text { Liczba } \\
\text { mieszkańców }\end{array}$ \\
\hline \multirow{3}{*}{ Belem } & 1749 & 6574 & \multirow{6}{*}{ Rio de Janeiro } & 1760 & 30000 \\
\hline & 1788 & 10620 & & 1780 & 38707 \\
\hline & 1801 & 12500 & & 1799 & 43376 \\
\hline \multirow{2}{*}{ São Luís } & 1757 & 7162 & & 1803 & 46944 \\
\hline & 1810 & 20500 & & 1808 & 65000 \\
\hline \multirow{2}{*}{ Fortaleza } & 1808 & 10000 & & 1819 & 113000 \\
\hline & 1819 & 16000 & \multirow{4}{*}{ São Paulo } & 1765 & 20873 \\
\hline \multirow{5}{*}{ Recife } & 1750 & 7000 & & 1798 & 21304 \\
\hline & 1776 & 18207 & & 1803 & 24311 \\
\hline & 1782 & 17954 & & 1819 & 25000 \\
\hline & 1810 & 25000 & \multirow{2}{*}{ Ouro Preto } & 1740 & 20000 \\
\hline & 1819 & 50000 & & 1804 & 7000 \\
\hline \multirow{4}{*}{ Salvador } & 1757 & 35922 & Vila Boa (Goiás) & 1804 & 9477 \\
\hline & 1775 & 36393 & \multirow{2}{*}{ Kurytyba } & 1799 & 4000 \\
\hline & 1780 & 39209 & & 1819 & 11000 \\
\hline & 1807 & 51000 & \multirow{3}{*}{ Porto Alegre } & 1777 & 2000 \\
\hline \multirow{2}{*}{ Oeiras } & 1762 & 1120 & & 1808 & 6035 \\
\hline & 1810 & 2000 & & 1819 & 12000 \\
\hline
\end{tabular}

Źródło: Opracowanie własne na podstawie: Alden 1987, s. 288, Conniff, Hendrix, Nohlgren 1971, s. 37.

i oczekiwaniem na przejęcie władzy po ojcu lub pozostaniem w Brazylii i ogłoszeniem jej niepodległości. Do tej drugiej opcji namawiali go usilnie przedstawiciele lokalnych elit oraz żona Leopoldyna, co skłoniło go do ogłoszenia deklaracji niepodległości Brazylii 7 września 1822 r. 1 grudnia tegoż roku koronował się na cesarza Piotra I (Kula 1987, Skidmore 1999).

Uzyskanie niepodległości było impulsem do zmiany statusu niektórych ośrodków miejskich. Z końcem 1822 r. Porto Alegre otrzymało prawa miejskie, a w następnym roku sześć kolejnych miasteczek będących stolicami prowincji zostało podniesionych do rangi miast, znalazły się wśród nich: Ouro Preto (dawna Vila Rica), Recife, Natal, Desterro (obecne Florianópolis), Fortaleza i São Cristóvão (stolica Sergipe). Ruch ten miał na celu podniesienie rangi tych ośrodków oraz prowincji, których były stolicami, a także wyrównanie nierówności w sieci miejskiej i umacnianie jedności narodowej (De Azevedo 1992). Poprawił również relatywnie niski wskaźnik umiastowienia Brazylii, która w momencie uzyskania niepodległości miała zaledwie 12 miast, a w wyniku powyższych zmian ich liczba wzrosła do 19. Sieć miejską uzupełniało jeszcze 213 miasteczek. 
Najwięcej spośród nich, bo aż 46,9\%, znajdowało się w regionie północno-wschodnim, w którym na pierwsze miejsce wysuwał się stan Bahia z 40 tego typu ośrodkami. $\mathrm{Na}$ kolejnej pozycji znalazł się region południowo-wschodni skupiający 32,9\% ogólnej ich liczby, a w jego obrębie uwagę zwraca stan São Paulo, w którym znajdowało się 31 miasteczek. Trzecią pozycję zajął region północny, w którym funkcjonowało 20 miasteczek, co stanowiło 9,4\% ogólnej ich liczby w Brazylii. Jeszcze gorzej sytuacja przedstawiała się w regionie południowym, gdzie istniało 17 (8\% ogólnej ich liczby) tego typu osiedli, oraz centralno-zachodnim, gdzie było ich tylko siedem (3,3\%) (tabela 1$)$.

\section{Podsumowanie}

Rozwój brazylijskiej sieci miejskiej w okresie kolonialnym może być dobrze wyjaśniony w myśl teorii systemu - sieci zaproponowanej przez Hohenberga i Lees (1995). W omawianym przypadku również główną siłą napędzającą urbanizację są powiązania i wymiana handlowa między miastami, przy czym warto podkreślić, iż pełniły one głównie funkcję punktów zbierających produkcję rolną wysyłaną następnie do metropolii. Zdecydowanie mniejszy przepływ towarów notowano z metropolii do powstałych miast, co wynikało z małej wielkości ich rynków wewnętrznych. Tworząca się sieć handlowa opierała się bezpośrednio na produkcji rolniczej, ponieważ to obszary wiejskie dostarczały surowców do handlu, a w mniejszym stopniu także żywności dla mieszkańców miast, natomiast jak już wspomniano wyżej, były one bardzo skąpymi rynkami zbytu, co wynikało z dominującego niewolniczego systemu pracy hamującego rozwój gospodarki pieniężnej.

Warto również podkreślić, iż większość ośrodków założonych w okresie kolonialnym ma genezę typowych miast-bram. Powstawały one zarówno w wyniku przesuwania się granic kolonizowanych obszarów, ale także jako ogniwa łączące dwie niezależnie rozwijające się sieci miejskie. W tej drugiej roli znalazły się z czasem główne porty regionalne Brazylii łączące ją z metropolią i światową siecią handlową. Jedyną liczącą się grupą ośrodków o odmiennej genezie powstania są miasta górnicze, w których to występowanie cennych kruszców było głównym czynnikiem miastotwórczym.

Powstała w okresie kolonialnym sieć miejska była stosunkowo niewielka i słabo wewnętrznie powiązana, nie tworzyła spójnego systemu krajowego, a raczej regionalne podsystemy skupione wokół głównych portów pełniących rolę miast-bram do poszczególnych regionów produkcyjnych. Ośrodki te rozwijały powiązania z miastami leżącymi w głębi lądu i pełniącymi rolę punktów zbiorczych skupiających produkcję eksportową wysyłaną do portu obsługującego dany region. W drugą stronę wędrowały importowane z zagranicy towary. Biorąc jednak pod uwagę niewielką chłonność wewnętrznych rynków, zdecydowanie dominował eksport towarów. W tej sytuacji miastami notującymi znaczący wzrost zaludnienia w drugiej połowie XVIII i pierwszym dwudziestoleciu XIX w. były jedynie porty wywozowe obsługujące poszczególne regiony produkcji eksportowej. W północnej części wybrzeża był to np. Belem, główny 
ośrodek prowincji Para i całej Amazonii obsługujący eksport ryżu i innych produktów rolnych. Jeszcze dynamiczniejszy rozwój na przełomie XVIII i XIX w. odnotowało São Luis - główny port regionu Maranhão obsługujący eksport trzciny cukrowej, ryżu, kakao, tytoniu i bawełny. W północno-wschodniej części wybrzeża podobne procesy odnotowano w przypadku: Fortalezy, Recife i Salvadoru. Każde z nich obsługiwało własne zaplecze produkcyjne, a sukces i rozwój danego portu warunkowało w dużej mierze zapotrzebowanie na eksportowane produkty na rynku europejskim. Porównując sytuację Brazylii w końcu okresu kolonialnego z modelem rozwoju systemu osadniczo-transportowego na obszarach kolonizowanych, można stwierdzić, iż znajdowała się ona na początku fazy czwartej (D) (rysunek 3).

W świetle merkantylnego modelu rozwoju sieci osadniczej Vance’a Brazylia znajdowała się również na początku czwartego etapu (rysunek 1), cechującego się wzrostem potencjału demograficznego i ekonomicznego pozwalającym na rozwój rynku wewnętrznego i początki lokalnej produkcji. W Brazylii uwidoczniło się to szczególnie w dwóch pierwszych dekadach XIX w., szczególnie po przeniesieniu się portugalskiego dworu królewskiego do Rio de Janeiro. Równolegle doszło do rozwoju i przesuwania osadnictwa w głąb kontynentu. Rosnący rynek wewnętrzny napędzał również import towarów z metropolii, przyspieszając jej wzrost, jednakże w tym przypadku korzyści te dyskontowała głównie Wielka Brytania, dzięki podpisanym umowom handlowym gwarantującym jej dominującą pozycję w handlu z Brazylią.

Wyraźną słabością procesu urbanizacji Brazylii w ostatnich dekadach okresu kolonialnego był stosunkowo niewielki rynek wewnętrzny i uzależnienie gospodarki kraju od eksportu produktów rolnych głównie do Europy. Oparcie gospodarki eksportowej na niewolniczej sile roboczej bardzo silnie ograniczało chłonność rynku wewnętrznego i hamowało rozwój miejscowego rzemiosła oraz początki industrializacji. Dlatego też większość miast była stosunkowo niewielkimi ośrodkami pełniącymi głównie funkcje usługowe. Krótkotrwały boom górniczy w Minas Gerais skończył się wraz z wyczerpaniem się złóż złota, a wraz z nim załamał się stosunkowo chłonny rynek wewnętrzny, jaki tworzyły miasta górnicze. Elity niepodległej Brazylii zainteresowane były zachowaniem ukształtowanego systemu gospodarczego i kontynuowaniem gospodarki eksportowej, co znacząco spowolniło procesu urbanizacji w tym kraju i odsunęło go w czasie.

\section{Bibliografia}

Alden D., 1987, Late colonial Brazil, 1750-1808, [w:] Colonial Brazil. Cambridge history of Latin America, vols. 1 and 2 selections, ed. L. Bethell, Cambridge University Press, Cambridge-New York.

Bird J.H., 1973, Of central places, cities and seaports, "Geography” 58(2).

Bird J.H., 1983, Gateways: slow recognition but irresistible rise, "Tijdschrift voor Economische en Sociale Geografie" 74(3).

Burghardt A.F., 1971, A hypothesis about gateway cities, "Annals of the Association of American Geographers" 61(2).

Castro de J., 1957, Um ensaio de geografia urbana: a cidade do Recife, [w:] Ensaios de geografia humana, ed. J. de Castro, Editôra Brasiliense, São Paulo. 
Christaller W., 1963, Ośrodki centralne w południowych Niemczech, „Przegląd Zagranicznej Literatury Geograficznej" 1.

Colonial Brazil. Cambridge history of Latin America, vols. 1 and 2 selections, 1987, ed. L. Bethell, Cambridge University Press, Cambridge-New York.

Conniff M.L., Hendrix M., Nohlgren S., 1971, Brazil, [w:] The urban development of Latin America 1750 1920, ed. R.M. Morse, Center for Latin American Studies, Stanford University, Stanford.

Deák C., Schiffer S., 2007, São Paulo: the metropolis of an elite society, [w:] The making of global city regions: Johannesburg, Mumbai/Bombay, São Paulo, and Shanghai, ed. K. Segbers, Johns Hopkins University Press, Baltimore.

De Azevedo A., 1992, Vilas e cidades do Brasil colonial, “Terra Livre - AGB” 10.

Furtado C., 1967, Rozwój gospodarczy Brazylii, przeł. J. Wrzoskowa, PWN, Warszawa.

Gardner J.A., 1972, Urbanization in Brazil, An International Urbanization Survey Report to the Ford Foundation. Ford Foundation, New York.

Hardoy J.E., 1978, European urban forms in the fifteenth to seventeenth centuries and their utilization in Latin America, [w:] Urbanization in the Americas from its beginnings to the present, eds. R.P. Schaedel, J.E. Hardoy, N. Scot Knizer, Mouton Publishers, Hague-Paris.

Hohenberg P.M., Lees L.H., 1995, The making of urban Europe 1000-1994, 2nd ed., Harvard University Press, Cambridge-London.

Johnson H.B., 1987, Portuguese settlement, 1500-1580, [w:] Colonial Brazil. Cambridge history of Latin America, vols. 1 and 2 selections, ed. L. Bethell, Cambridge University Press, Cambridge-New York.

Krzysztofik R., 2003, Pojęcie genotypu funkcjonalnego w badaniach nad układami lokalizacyjnymi miast przegląd badań i próba modelu, „Czasopismo Geograficzne” 74(4).

Krzysztofik R., 2004, Miasta-wrota. Zarys teorii i przeglad badań, „Czasopismo Geograficzne” 75(3).

Krzysztofik R., 2009, Układ lokalizacyjny miast typu system - sieci na obszarze Polski, Wydawnictwo Uniwersytetu Śląskiego, Katowice.

Kula M., 1987, Historia Brazylii, Ossolineum, Wrocław-Warszawa.

Leitman S.L., 1978, A Brazilian urban system in the nineteenth century: Pelotas and Rio de Janeiro, [w:] Urbanization in the Americas from its beginnings to the present, eds. R.P. Schaedel, J.E. Hardoy, N. Scot Knizer, Mouton Publishers, Hague-Paris.

Maik W., 1988, Rozwój teorii regionalnych i krajowych układów osadnictwa, Wydawnictwo UAM, Poznań. Geografia nr 37.

Mauro F., 1978, Urban preeminence and the urban system in colonial America, [w:] Urbanization in the Americas from its beginnings to the present, eds. R.P. Schaedel, J.E. Hardoy, N. Scot Knizer, Mouton Publishers, Hague-Paris.

Morse R.M., 1974, Brazil's urban development colony and empire, "Journal of Urban History" 1(1).

Morse R.M., 1978, Cities and society in nineteenth-century Latin America: The illustrative case of Brazil, [w:] Urbanization in the Americas from its beginnings to the present, eds. R.P. Schaedel, J.E. Hardoy, N. Scot Knizer, Mouton Publishers, Hague-Paris.

Rogers E.J., 1962, The iron and steel industry in colonial and imperial Brazil, "The Americas" 19(2).

Schwartz B.S., 1987, Plantations and peripheries c. 1580 - c. 1750, [w:] Colonial Brazil. Cambridge history of Latin America, vols. 1 and 2 selections, ed. L. Bethell, Cambridge University Press, Cambridge-New York.

Silva A.M.D., 1987, Imperial re-organization, 1750-1808, [w:] Colonial Brazil. Cambridge history of Latin America, vols. 1 and 2 selections, ed. L. Bethell, Cambridge University Press, Cambridge-New York.

Silva S.C.B. de M. e., Leão S. de O., Silva B.C.N., 1989, Urbanizaçáo e metropolizaçáo no estato da Bahia: evoluçáo e dinâmica, Centro Editorial e Didático da UFBA, Salvador.

Simmons J.W., 1983, The settlement systems of virgin lands, "Geographia Polonica" 47.

Skidmore T.E., 1999, Brazil: Five centuries of change, Oxford University Press, New York-Oxford.

Smith R.C., 1955, Colonial towns of Spanish and Portuguese America, "Journal of the Society of Architectural Historians" 14(4).

Taaffe E.J., Morrill R.L., Gould P.R., 1963, Transport expansion in underdeveloped countries: A comparative analysis, "Geographical Review" 53(4).

Vance J.E., Jr., 1971, Merchant's world: The geography of wholesaling, Prentice Hall, Englewood Cliffs. 
Vidal L., 2008, Mazagan miasto które przepłynęło Atlantyk. Z Maroka do Amazonii (1769-1783), przeł. M.M. Berger, Państwowy Instytut Wydawniczy, Warszawa.

Wallerstein I., 2011, The modern world-system, 1: Capitalist agriculture and the origins of the European world-economy in the sixteenth century, 2nd ed., University of California Press, Berkeley-Los Angeles-London.

Whebell C.F.J., 1969, Corridors: A theory of urban systems, "Annals of the Association of American Geographers" 59(1).

Wyrobisz A., 1989, Nowe koncepcje w badaniach nad historia miast europejskich, „Przegląd Historyczny” $80(1)$. 